\title{
MÉTRICA Y ARQUITECTURA DEL HOSPITAL DE LOS REYES CATÓLICOS EN SANTIAGO DE COMPOSTELA
}

\author{
Víctor GRANDE Nieto \\ Doctor Arquitecto
}

Copyright: (C) 2016 CSIC. Este es un artículo de acceso abierto distribuido bajo los términos de una licencia de uso y distribución Creative Commons Attribution (CC-by) España 3.0.

Cómo citar/Citation: Víctor Grande Nieto, "Métrica y arquitectura del Hospital de los Reyes Católicos en Santiago de Compostela”, Cuadernos de Estudios Gallegos, 63, núm. 129 (2016), págs. 287-342, DOI: http://dx.doi.org/10.3989/ceg.2016.129.08 


\section{MÉTRICA Y ARQUITECTURA DEL HOSPITAL DE LOS REYES CATÓLICOS EN SANTIAGO DE COMPOSTELA}

RESUMEN

Aunque los Reyes Católicos protegieron varios hospitales en diferentes ciudades de la península, promovieron dos directamente: el de Santiago y el de Granada, que presentan en su idea matriz el corpus arquitectónico del contenedor bien definido y aislado en el que caben multitud de funciones y de asistencias. No son por lo tanto simplemente hospitales, su función representativa como edificio Real para interés público es tanto o más importante que la sanitaria, ya que no es casual que estén construidos en dos ciudades en las que los Reyes justamente necesitaban tener más presencia.

El gran logro de la Corona no fue tanto el otorgar a sus fábricas una decoración determinada, sino el insertarlas en el espacio urbano como monumento simbólico de la nueva imagen de poder.

Los análisis planimétricos correspondientes nos muestran un edificio bien trabado, en el cual se comprueba que Egas se basó en las medidas ciertas, el principio de los números enteros pequeños y el sistema escalar, para aplicar las Artes Quadrivium al Hospital Real y así dignificarlo, al alcanzar la disciplina arquitectónica el status de Arte Mayor.

Palabras clave: Hospital de los Reyes Católicos, Santiago de Compostela, Egas, Arquitectura, Rodrigo Gil de Hontañón.

\section{MÉTRICA E ARQUITECTURA DO HOSPITAL DOS REIS CATÓLICOS EN SANTIAGO DE COMPOSTELA}

RESUMO

Inda que os Reis Católicos protexeron varios hospitais en diferentes cidades da península, promoveron dous directamente: o de Santiago e o de Granada, que presentan na súa idea matriz o corpus arquitectónico do contedor ben definido e illado no que caben multitude de funcións e de asistencias. Non son polo tanto simplemente hospitais, a súa función representativa como edificio Real para interese público é tanto ou mais importante que a sanitaria, xa que non é casualidade que estean construídos en duas cidades nas que os Reis xustamente precisaban ter mais presenza.

O gran logro da Coroa non foi tanto o outorgar as súas fábricas unha decoración determinada, senon o insertalas no espazo urbán como monumento simbólico da nova imaxe de poder.

As análises planimétricas correspondentes nos amosan un edificio ben trabado, no que se comproba que Egas se basou nas medidas certas, o principio dos números enteiros pequenos e o sistema escalar, para aplicar as Artes Quadrivium ao Hospital Real e así dignificalo, ao alcanzar a disciplina arquitectónica o status de Arte Maior.

Palabras clave: Hospital dos Reis Católicos, Santiago de Compostela, Egas, Arquitectura, Rodrigo Gil de Hontañón.

\section{METRIC AND ARCHITECTURE OF THE CATHOLIC KINGS' HOSPITAL IN SANTIAGO DE COMPOSTELA}

ABSTRACT

The Catholic Kings protected several hospitals in different cities of the peninsula but promoted two directly: one in Santiago and one more in Granada, that present in its idea matrix the architectural corpus of the container well defined and isolated in that are included multitude of functions and of assistances. They are not simply hospitals, his representative function like Real building for public interest is so much important that the sanitary, it is not casual that are built in two cities in the that the Kings needed to have more presence.

The grain attainment of the Crown was not so it awards his factories a decoration determined, else that they inserted in the space urban like symbolic monument of the new image of power.

The analyses drawing corresponding show us a well tied building, in the that checks that Egas based in the true measures, the principle of the small whole numbers and the scale system, to apply the Arts Quadrivium to the Real Hospital and like this dignify, and the architectural discipline achieve the status of Greater Art.

Key words: Catholic Kings' Hospital, Santiago de Compostela, Egas, Architecture, Rodrigo Gil de Hontañón. 
uando los Reyes Católicos vinieron al antiguo reino de Galicia en 1486, lo hicieron para mandar proveer e castigar las cosas del Bierzo e del Reyno de Galizia e visitar las reliquias e iglesia del Apóstol Santiago nuestro patrón, y es que debían apaciguar las continuas tensiones sociales y políticas que existían en este cuadrante peninsular, en donde aún rezumaban las secuelas de las Revoltas Irmandiñas. Entre otros cometidos: mediaron en los continuos conflictos entre la nobleza y los delegados reales, contentaron a los municipios que reclamaban mayor autonomía, y a los monasterios que querían desprenderse de los encomenderos y valedores, liquidaron el bandolerismo y las inquietudes de los caballeros destruyendo hasta veinte fortalezas, hicieron salir de Galicia a los caballeros más turbulentos encaminándolos a la guerra de Granada y recaudaron fondos con destino a dicha empresa ${ }^{1}$.

En su estadía compostelana comprobaron in situ la incapacidad de los pequeños e insalubres hospitales, por lo que decidieron fundar uno con el fin de racionalizar los costos y mejorar la atención. Dicho hospital sería el culmen de la red que a lo largo del Camino de Santiago se fue articulando para dar ayuda y atención a los peregrinos.

Al principio surge la idea de monasterio-hospital vinculado a San Martín Pinario, pero dicha tentativa de la Corona se frustró en los años sucesivos por dos motivos: primeramente se encontraron con la oposición del reacio abad comendatario de San Martín Pinario: don Diego de Muros I (obispo de Tui 1472-1487 y Ciudad Rodrigo 1487-1492) y de sus correligionarios de San Pedro y San Paio Antealtares (abadías que pasarían a formar parte de las rentas de San Martín para poder asumir éste los costos de la obra y sustentación del hospital), lo cual demoró el proceso constructivo varios años. Cuando solventaron el asunto de los abades comendatarios, los Reyes Católicos se encontraron ante la imposibilidad de que un monasterio de la Congregación vallisoletana, a la que se adhiere San Martín

\footnotetext{
1 José García Oro, Galicia en los siglos XIV y XV, A Coruña, Fundación Pedro Barrié de la Maza, 1987 (Colección Galicia Histórica), pág. 371.
} 
en 1495, ejerza funciones de hospicio, por ello se inclinan finalmente a la idea de un hospital autónomo regido por la Corona ya que de esta forma les aportará identidad y presencia en una ciudad totalmente eclesiástica, no sin antes exigir a la propia Congregación benedictina que contribuyese a sustentar el hospital económicamente en conformidad con los establecido por las bulas pontificias. Tal contribución nunca iba a llegar, aunque afortunadamente los reyes pudieron establecer otros canales de financiación.

Aunque inicialmente la causa principal de la fundación de esta obra pía se deba al hecho de economizar o rentabilizar la función hospitalaria en Compostela, al hilo de lo anteriormente dicho, el Hospital Real tendrá definitivamente un carácter instrumental al servicio de la Corona, concepto que prevalece sobre la pureza de los modelos formales ${ }^{2}$. Los Reyes Católicos ven la oportunidad de aunar en una fábrica áulica los tres factores por los que vinieron a Galicia: el social, el político y el religioso, consiguiendo con esta obra, la identidad y presencia que necesitaban en una ciudad dominada totalmente por el arzobispo.

El Hospital Real de Santiago de Compostela nace definitivamente el 3 mayo de 1499, a partir del Poder y Memorial que dictan los Reyes Católicos. Este Hospital fue trazado por Enrique y Antón $\operatorname{Egas}^{3}$, y junto con sus otras dos realizaciones hospitalarias: el Hospital de la Santa Cruz de Toledo y el Hospital Real de Granada, contribuyeron al proceso de modernización de esta tipología en la península, ya que forman parte de un conjunto de edificios, consecuencia de todo un recorrido que se desarrolla en la península itálica, enmarcado en una línea de salubridad e higiene que quizás alcanzó en Santiago el grado máximo en sus planteamientos.

\section{ARQUETIPO HOSPITALARIO}

En la cultura griega o en la romana no se desarrollaron propiamente lugares de acogida para los necesitados de todo tipo. Este concepto de ayuda al necesitado surge

\footnotetext{
2 Joaquín Yarza Luaces, Los Reyes Católicos. Paisaje artístico de una monarquía, Madrid, Ediciones Nerea S.A., 1993, pág. 389. José Policarpo Cruz CABRERA, "La escultura castellana en tiempos de Doña Isabel la Católica: de la tradición medieval a la modernidad humanista" en Juan Manuel Martín García (ed.), Modernidad y cultura artística en tiempos de los Reyes Católicos, Granada, EUG, 2014, págs. 89-114.

3 No es posible discernir exactamente la implicación de cada hermano en esta obra puesto que documentalmente tan sólo se constata la presencia en obra en repetidas ocasiones de Enrique Egas, por lo que de forma generalizada se ha estimado que Enrique Egas habría sido el único artífice de dicha obra en detrimento de Antón. No tenemos la certeza de que ello fuera así, aunque tampoco tenemos argumentos sólidos que ratifiquen o desmientan tal afirmación, pero en todo caso nos gustaría dejar en cuarentena la autoría de esta fábrica, ya que tampoco sería descabellado pensar que, en la organización de su taller, Antón fuese el responsable de las trazas y Enrique el responsable de gestionar su construcción.
} 
con el cristianismo, sobre todo al dejar de estar proscrito en el Imperio Romano a partir del año 313 d.C., puesto que tras el Consejo de Nicea en Bitinia en el año 325 d.C., los más de 300 obispos allí presentes se propusieron construir diferentes casas de beneficencia, y es que la Iglesia era por entonces la única autoridad capaz de gestionar la ayuda a los necesitados en esta época de enfermedades y continuas guerras. Para ello edificaron diferentes casas según su finalidad: para los expósitos el Brephotrophium, para los huérfanos el Orphanotrophium, para los enfermos Nosocomium, para los ancianos el Gerentochomium, para toda clase de pobres el Ptochotrophium, y para los extranjeros el Xenodochium, que era propiamente el hospital o casa de la hospitalidad, ya que atendía a los forasteros "hospes". Del primero que tenemos constancia es el Xenodochium de Porto, ubicado en la desembocadura del río Tíber, realizado alrededor del año 370.

Durante el siglo $\mathrm{V}$ fueron aumentando el número de casas de refugio, fundando los primeros hospitales monacales entre los siglos VI y el VII, como el de la célebre abadía benedictina de Montecassino del año 529.

Otro de los hitos ineludibles es la realización del plano ideal del monasterio benedictino de Saint Gallen en torno al año 820. En el plano aparecen estructurados multitud de edificios articulados sobre una cuadrícula, donde cada uno presenta una función y cometido determinado. La evolución de los conceptos expresados en el plano son anteriores al mismo, si bien aquí alcanza un elevado grado de perfección esquemática. Entre los edificios que se disponen en el monasterio existe una casa para huéspedes distinguidos hospitum, y una casa para pobres y peregrinos pauperum et peregrinorum, conceptos muy ligados en la Edad Media puesto que el ideal de pobreza evangélica exigía andar por los caminos a expensas de la caridad del prójimo. Destaca entre los diferentes edificios del monasterio, el hospital para los monjes: infirmarium; estructurado con una claustro porticado que alberga en sus dependencias las funciones de: refectorio, amplia sala, sala de enfermos graves, sala para el magister, calefacción, dormitorio con letrinas e iglesia, e incluso una fuente ubicada en el centro del prado, haciendo de este edificio un ente autónomo. Esta singular y característica unión del edificio hospitalario con la iglesia tiene su origen en la ideología medieval, donde la asistencia espiritual ha prevalecido sobre la asistencia médica, sanitaria, higiénica o social ${ }^{4}$.

\footnotetext{
4 Dankwart Leistikow, Edificios hospitalarios en Europa durante diez siglos. Historia de la arquitectura hospitalaria, C. H. Boehringer Sohn, Ingelheim am Rhein, 1967, págs. 15-16. Delfín GARCíA Guerra, El Hospital Real de Santiago (1499-1804), A Coruña, Fundación Pedro Barrié de la Maza. 1983, pág. 29. Mercedes Insua CABAnas, “Arquitectura Hospitalaria en Galicia” en Xose Manuel García Iglesias (coord.), O Hospital Real de Santiago de Compostela e a hospitalidade no camiño de peregrinación, A Coruña, Xunta de Galicia, 2004, págs. 57-85. Abate Bergier, Diccionario enciclopédico de teología, Tomo IV, trad. Ramón García Consul, Madrid, 1832, pág. 629.
} 
La Orden Cluniacense y la Cisterciense aplicaron esquemas similares que se fueron reestructurando con el paso de los siglos.

Existían también hospicios, destinados a albergue provisional. Su construcción nace del deber de ofrecer alojamiento y protección a peregrinos y viajeros en tierras inhóspitas. Son de especial importancia aquellos que vertebran los caminos hacia Roma y Santiago de Compostela, así como los de los países Nórdicos. El más influyente fue Santa María della Scala en Siena, que data ya del siglo XI, y que poco a poco se convirtió en hospital, practicando también la caridad, dando comidas en épocas de hambrunas y acogiendo a huérfanos. Tuvo varias salas yuxtapuestas sin un orden ni planimetría definida. Su importancia estriba en el hecho de utilizar vastas salas y una organización simétrica de camas, siendo reputado por sus extraordinarias condiciones higiénicas y su eficacia.

En el siglo XII y XIII se desarrolla el concepto de sala, de una sola planta y una o varias naves, cuya idea fundamental estribaba en aunar a todos los asistidos en un único espacio a modo de comunidad, donde el altar se dispusiera en el punto central de la composición. Aunque los mejores ejemplos se encuentren en Francia e Inglaterra, en España también podemos rastrear estas salas en Vich, Burgos y Tarragona, alcanzando su máxima madurez en el siglo XV en el Hospital de Santa Cruz de Barcelona 5 .

El aumento de la población en las ciudades así como el aumento de riqueza de la burguesía a partir del siglo XII, provocarán que los monasterios y fundaciones capitulares pierdan la exclusividad de esta actividad, apareciendo el hospital civil o burgués que se emplazó progresivamente intramuros, y que desligará hospital e iglesia; aunque en España la secularización del hospital fue ínfima sí la comparamos con el resto de Occidente, ya que se conservó una mentalidad de fuerte tinte religioso en la vida social ${ }^{6}$.

El Ospedale di Santa Maria Nuova de Florencia, fundado entre 1285 y 1288, centra su influencia en separar los sexos en diversas naves, así como en la colocación de altares sobre montados por cúpulas en el cruce de los brazos. Se creía que ya estaba configurado en el año 1334 en forma de cruz, pero hasta 1479 disponía sólo de dos brazos que se cruzaban en el altar?

Será en el Quattrocento cuando se desarrolle en Italia una arquitectura hospitalaria en forma de palacio, cuyas características más relevantes son la planta

\footnotetext{
5 Dankwart Leistikow, Edificios hospitalarios en..., págs. 27, 34.

6 Begoña Fernández Rodríguez, "La hospitalidad medieval, el hospital viejo de Santiago de Compostela”, en Memoria Artis, A Coruña, Xunta de Galicia, 2003, pág. 72. Dankwart LeIsTikow, Edificios hospitalarios en..., pág. 55.

7 Mercedes Gómez-Ferrer Lozano, Arquitectura en la Valencia del Siglo XVI, el Hospital General y sus artífices, Valencia, Albatros, 1998, págs. 45-50.
} 
cruciforme y los patios columnados sobre los que se disponen las salas de los enfermos. Anteriores a la mitad de la centuria encontramos ejemplos tan notables como los hospitales de Brescia, de Pavia y de Mantua, pero en 1456 Filarete recoge todas estas experiencias y diseña el Ospedale Maggiore en Milán, que se convierte en el canon indiscutible: se articula dispuesto en elementos geométricos básicos donde un gran patio central rematado por una iglesia divide dos zonas, organizándose cada una de ellas mediante una cruz griega que distribuye cuatro patios.

La paradigmática y colosal planta del Ospedale Maggiore no pudo pasar indiferente al hospital compostelano si pretendía para los Reyes Católicos ser oído en todo el mundo, ya que la Corona le otorgaba a este edificio gran importancia como símbolo de su poder ${ }^{8}$. El hospital compostelano comparte con el milanés la idea Humanística del corpus arquitectónico: se componen en figuras simples que son los contenedores de la totalidad de la obra, a partir del que se extrae un proceso de división modulada para el establecimiento derivado de las partes de lo general a lo particular, oponiéndose frontalmente a los métodos aditivos de la construcción medieval de lo particular a lo general ${ }^{9}$. Incluso en el Tratado filaretiano encontramos ilustraciones planimétricas cercanas al esquema compostelano ${ }^{10}$.

Aunque no presenta forma cruciforme, citamos como último eslabón italiano al Ospedale di Santo Spiritu in Sassia de Roma, construido entre 1474 y 1478, que se inscribe en forma de T, siendo el más famoso de los hospitales romanos, gozando de amplios privilegios e indulgencias que adquirirán con el tiempo los hospitales españoles.

En cuanto a los posibles precedentes peninsulares del hospital compostelano, nombraremos en primer lugar al Hospital Real de Todos os Santos de Lisboa, realizado entre 1492 y 1504 , que aunque no se conserva nada debido al terremoto de Lisboa, según se desprende de las disposiciones testamentarias que Don João II le encomienda a su sucesor Don Manuel, el Hospital fue inspirado sobretodo en los hospitales de Florencia y Siena. Este hospital supuso una simplificación

\footnotetext{
8 Ha este respecto Cambil Hernández defiende el posible conocimiento, y por consiguiente, la correlativa influencia del Tratado filaretiano en los hospitales de Egas. Puesto que los hospitales de Egas, poseyendo como el de Milán una decoración profusamente gótica, incorporan a nuestro renacimiento, de una forma definitiva, la planta de cruz con altar central, pura expresión en el fondo de postulados neoplatónicos y punto de encuentro entre el añorar una antigua cultura iconográfica y la nueva interpretación de las nuevas relaciones posibles entre el mundo y el hombre. María de la Encarnación CambIL Hernández, Los hospitales de Granada: (siglo XVI-XXI) Tipología, Catálogo e historia, Granada, Universidad de Granada, 2010, págs. 226-227.

9 Joaquín Arnau Amo, La teoría de la arquitectura en los tratados, Albacete, Artes gráficas Flores, 1988, Vol. III, pág. 7-15.

${ }^{10}$ Antonio Averlino "Filarete", Tratado de arquitectura, Pilar Pedraza (ed.), Vitoria-Gasteiz, Ephialte, Instituto de Estudios Iconográficos, 1990, págs. 186, 190.
} 
de los anteriores en línea con los del Quatroccento italiano, por ello su disposición planimétrica tiene notables parecidos a los Hospitales Reales realizados por Egas ${ }^{11}$.

Algunos historiadores han situado como referentes directos de los Hospitales de Egas a los realizados anteriormente en Zaragoza y Valencia.

En lo que se refiere al Hospital Real y General de Nuestra Señora de Gracia de Zaragoza, el concepto de su hipotética tipología cruciforme lo introdujo Wilkinson ${ }^{12} \sin$ justificar el dato y esta idea ha sido repetida sin argumentos convincentes hasta nuestros días. Lo cierto es que este hospital no presenta una estructura coordinada, sistemática y armónica, sino todo lo contrario, y aunque esto se deba en parte a todos los anexos posteriores, según las descripciones de los estudios monográficos ${ }^{13}$ : la iglesia se sitúa en una esquina, existe un gran patio, se dan corredores pegados a la fachada y existen grandes problemas de ventilación, por lo tanto descartamos su vinculación como modelo predecesor del Compostelano.

En cuanto al Hospital General de Valencia existe la posibilidad de que su traza en cruz se realizase hacia el año 1494, anterior a cualquiera de los proyectos de Egas. Esta traza pudo venir de Italia o al menos estar muy influenciada por todos los hospitales cruciformes existentes en la península itálica, adaptándose posteriormente a la realidad constructiva vigente en Valencia por un maestro local ${ }^{14}$. Posiblemente sobre esta traza se realizaron algunas modificaciones cuando se decidió aprovechar el Hospital dels Folls o Inocentes para que sirviera de base a las nuevas enfermerías del Hospital General, pero este Hospital General construye básicamente los dos primeros brazos de la cruz entre 1513-1517, retomando en 1538 la construcción para los siguientes brazos. Por lo tanto no se descarta la influencia recíproca entre los hospitales de Egas y el valenciano, aunque es poco probable que este último tenga mayor influencia en los de Egas que el resto de los hospitales señalados anteriormente. En todo caso, tendría más sentido relacionar proyectualmente el Hospital General de Valencia y el Hospital de Santa Cruz de Toledo.

\footnotetext{
${ }^{11}$ Mário CARmona, O Hospital Real de Todos os Santos da Cidade de Lisboa, Lisboa, 1954, pág. 120 Paulo Pereira, "Construçoes na "Gran Estrada": O Caminho de Santiago e a Arquitectura Portuguesa (1400-1521)", en Xosé Carlos Valle Pérez (coord.), Do Tardogótico ó Manierismo. Galicia e Portugal, Fundación Pedro Barrié de la Maza / Fundaçao Calouste Gulbenlian, 1995, págs. 75-130.

${ }^{12}$ M. Gómez-Ferrer Lozano, Arquitectura en la Valencia..., pág. 40.

${ }_{13}$ Aurelio Baquero, Bosquejo histórico del Hospital Real y General de Nuestra Señora de Gracia de Zaragoza, Zaragoza, Institución Fernando el Católico, 1952. Asunción Fernández Doctor, El Hospital Real y General de Ntra. Sra. De Gracia de Zaragoza en el siglo XVIII, Zaragoza, Institución Fernando el Católico, 2000.

${ }^{14}$ M. Gómez-Ferrer Lozano, Arquitectura en la Valencia..., pág. 68.
} 
En el memorial de los Reyes Católicos para la fundación del Hospital Real de Santiago de Compostela no faltaron las referencias a otros hospitales para que fueran tomados como modelo: el Hospital del Rey de Burgos y el del monasterio de Guadalupe, pero entiéndanse estos casos nunca como modelos arquitectónicos sino como referencias hospitalarias existentes dentro de la Corona, puesto que el primero era famoso por ser hospital de peregrinos y el segundo también tenía gran popularidad, aunque afortunadamente ejercieron nula influencia arquitectónica en el hospital compostelano.

Descartando pues todos los diseños arquitectónicos de Castilla y Aragón, nos centramos definitivamente en la influencia del arquetipo italiano, siendo el hospital de Milán y el de Roma los más complejos y admirados, aunque sería erróneo atribuirles una influencia directa y única en el de Santiago puesto que en Italia por aquel entones eran muchas las ciudades que disponían de hospital cruciforme (e incluso en Lisboa), por ello entendemos suficientemente argumentado el hecho de que no existe un modelo que imitar sino que Egas se basa en la tipología hospitalaria que se desarrolla en el siglo XV en Italia para, a partir de ella, desarrollar sus arquitecturas hospitalarias en la península.

Aún sin estar claro el origen de esta arquitectura, se puede llegar a entrever una secuencia temporal cuyo origen de patio con columnas partiría de la herencia antigua clásica, siendo adoptado en el Xenodochium de Porto (no sabemos si fue regla generalizada para todos), seguidamente en las infirmarium monacales como en Montecassino y Saint Gallen, persistiendo en la arquitectura hospitalaria medieval italiana como en Florencia y Siena, para finalizar en el Quattrocento con el posterior desarrollo del palacio hospitalario italiano de cuyos múltiples ejemplos destaca el milanés.

Estos hospitales se enmarcan en una secuencia temporal de continuos avances en los conceptos, desarrollos y técnicas, así pues el Hospital Real de Santiago se inscribe como parte de esa secuencia, aplicando y ampliando los conceptos más desarrollados y perfeccionados hasta la fecha. Tras el compostelano, se construirán en la península ibérica espléndidos ejemplos en Sevilla, Toledo, Granada y Medina del Campo, que seguirán evolucionando esta tipología, la cual se mantendrá vigente hasta el siglo XIX.

\section{Planta}

La arquitectura y el arte en general eran temas secundarios para los Reyes Católicos puesto que consolidar el Reino fue una tarea demasiado ardua y onerosa como para entretenerse en demasía en las fábricas áulicas, pero ello no impidió que todo aquello que promovieron tuviese un criterio y finalidad específica. El gran logro de la Corona no es otorgarle a sus fábricas una decoración o estilo de- 
terminado, algo que ellos no definían ${ }^{15}$, sino insertarlas en el espacio urbano como un monumento simbólico de la nueva imagen de poder. Así pues promovieron directamente dos hospitales: el de Santiago y el de Granada, que a diferencia del resto, que no fueron directamente auspiciados por la Corona, presentan en su idea matriz la reiterada alusión al corpus arquitectónico del contenedor bien definido y aislado en el que caben multitud de funciones y de asistencias. No son por lo tanto simplemente hospitales, su función representativa como edificio Real para interés público es tanto o más importante que la sanitaria. No es casual que estén construidos en dos ciudades en las que los Reyes necesitaban tener más presencia: en una por ser la ciudad-santa del territorio hispano -controlada completamente por los arzobispos Fonseca- y en la otra por ser la ciudad-emblema de la nueva monarquía al haberla reconquistado recientemente a los musulmanes. Edificar para los Reyes Católicos suponía un medio para reforzar su poder, habida cuenta de que la arquitectura permanece enraizada en la tierra, constituyendo en sí misma un símbolo de prestigio y autoridad, por ello la arquitectura tenía un alto valor representativo puesto que el edificio en sí podía hacer presente su ausencia, como si sus reales personas lo habitasen ${ }^{16}$. En ambas ciudades debían ganarse a sus gentes, y la presencia de una Institución Real, pública y caritativa, era la forma más idónea.

El Hospital introdujo en Compostela una nueva escala de edificio civil y otorgó una nueva dimensión al espacio público y al tejido urbano medieval. Su gran masa arquitectónica genera el espacio urbano de sus inmediaciones, como ocurría en el Quattrocento italiano; indicativo de que la forma arquitectónica tenía una importancia predominante y simbólica en sí misma.

El Hospital Real se trazó en cruz latina, como se especifica en el Memorial de 1499, comenzándose en 1501 y terminándose en lo esencial en 1511, fecha señalada en la inscripción del friso del segundo cuerpo de la portada principal.

A su interior se accede por medio de un zaguán dispuesto en el centro de su lienzo meridional, y mediante un doble quiebro ortogonal nos adentra en los dormitorios de los peregrinos o bien en sendos patios, que son los que organizan y distribuyen el resto de las dependencias. Estos patios están dispuestos equidistantes respecto el eje central que marca la capilla, verdadera alma mater del edificio, ya que desde ella se propagaba la palabra de Dios a los convalecientes sin necesidad de que se levantasen de sus camas gracias a su altar elevado que llegaba a los tres pabellones de enfermos, puesto que además de curar el cuerpo se curaba también el alma.

\footnotetext{
${ }_{15}$ Joaquín Yarza Luaces, Los Reyes Católicos..., pág. 87.

${ }^{16}$ Andrés Rosende Valdés, "Los Reyes Católicos y Compostela: política y devoción”, Semata, 10 (1998), pág. 165.
} 
En el momento fundacional no estaba pensado para la atención a la población local, cubierta en teoría por las instituciones existentes, sino que su cometido era solamente la atención a los peregrinos, pero este enfoque se modificó en 1507, cuando la Corona solicita y obtiene una bula del Papa Julio II ordenando la supresión de los quatro hospitais que havía en la ciudad de Santiago y el paso de sus rentas al nuevo, superando así la idea inicial de un hospital exclusivo para peregrinos ${ }^{17}$. Tampoco aparece mencionada la finalidad de acoger a los niños expósitos, ni en la Carta de Fundación, ni en los demás documentos anteriores a 1512, fecha en la que se concede al Hospital Real los mismos privilegios que gozaba el Santo Spirito in Sassia ${ }^{18}$.

Aunque el intento de fusión de rentas de los otros hospitales de la ciudad se vio definitivamente frenado por el Consejo Real en 1546, el Hospital necesitaba ampliar la fábrica para dar cabida a las nuevas funciones que deseaba ejercer, por lo que entorno a los años veinte se pudo haber proyectado dicha ampliación, ya que en 1527 consta documentalmente que se estaban a realizar la obra de los patios nuevos $^{19}$, de la que hablaremos más adelante.

\section{MÉTRICA}

La arquitectura en sí no deriva de una suma de longitudes, anchuras y alturas de los elementos constructivos que envuelven el espacio, sino que dimana propiamente del vacío, del espacio envuelto, del espacio interior, el cual se debe vivir por experiencia directa, aunque para poder aprehender y apropiarnos de los principios que la rigieron deberemos estudiar su métrica.

Los diversos sistemas de medidas utilizados tradicionalmente en España tienen sus orígenes en el sistema metrológico romano, instaurado en la Península tras su colonización. En lo que respecta a la arquitectura, se creó un sistema antropométrico cuya base radicaba en el pie, que es la sexta parte del cuerpo humano (concretamente se utilizó el pie capitolino de 0,296 m.). Tras la disgregación del Imperio Romano, la unidad metrológica se resquebraja, siendo notoria la importancia que adquiere la vara de 3 pies como patrón de medida por su dimensión cómoda para los maestros.

El primer intento de unificar medidas del que tenemos constancia en nuestro país se remonta al año 1261 cuando Alfonso X el Sabio establece como patrón la

\footnotetext{
${ }_{17}$ Ofelia Rey Castelao, "A Historia do Real Hospital de Santiago", en Xose Manuel García Iglesias (coord.), O Hospital Real de Santiago de Compostela e a Hospitalidade no Camiño de Peregrinación, A Coruña, Xunta de Galicia, 2004, págs. 375-396.

${ }^{18}$ D. García Guerra, El Hospital Real..., pág. 321.

${ }_{19}$ Andrés Rosende Valdés, El Grande y Real Hospital de Santiago de Compostela, Santiago de Compostela, Electa, 1999, págs. 165.
} 


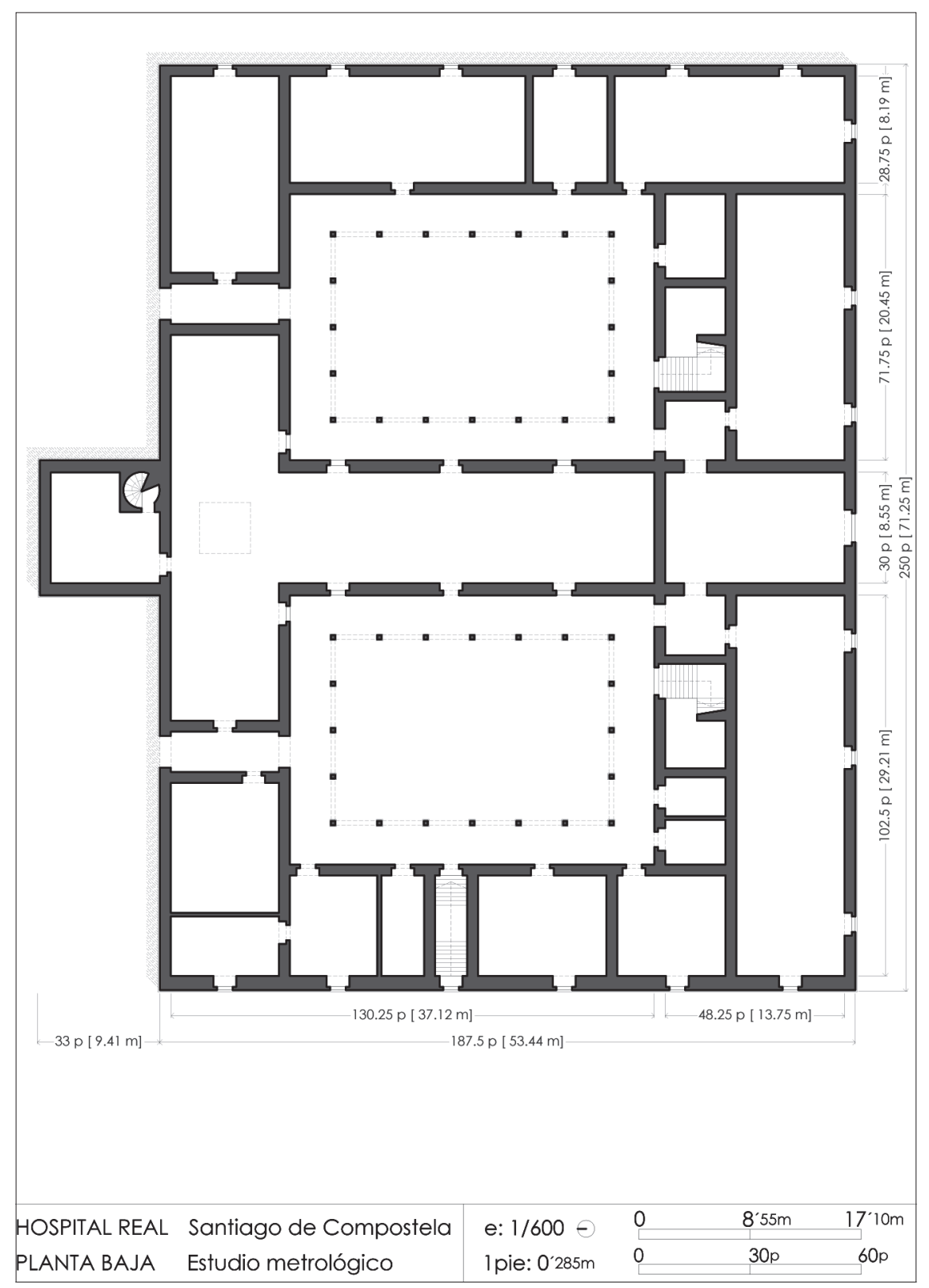

Fig. 1. Hospital Real. Planta baja. Estudio metrológico. Plano propio. 


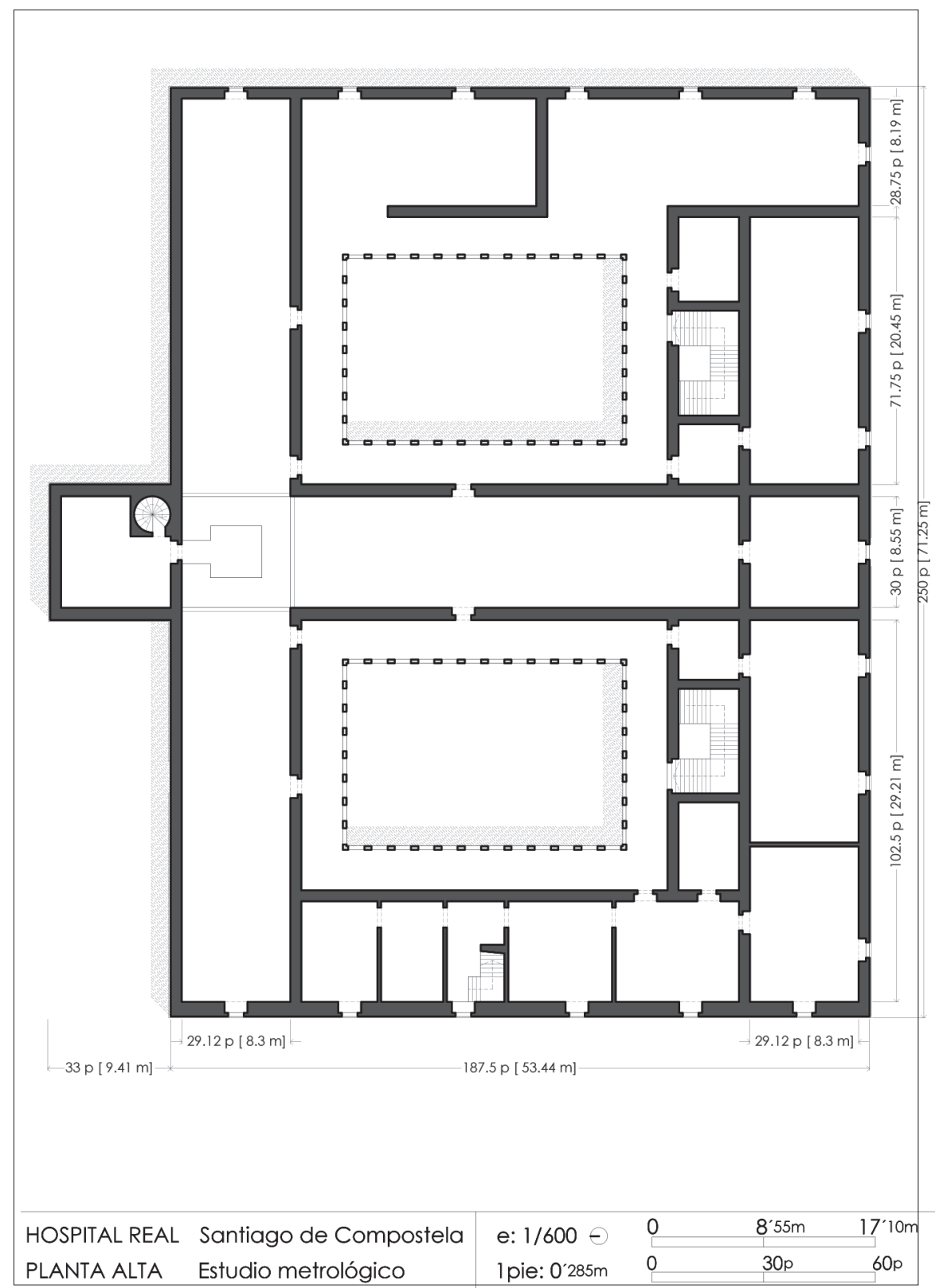

Fig. 2. Hospital Real. Planta alta. Estudio metrológico. Plano propio. 


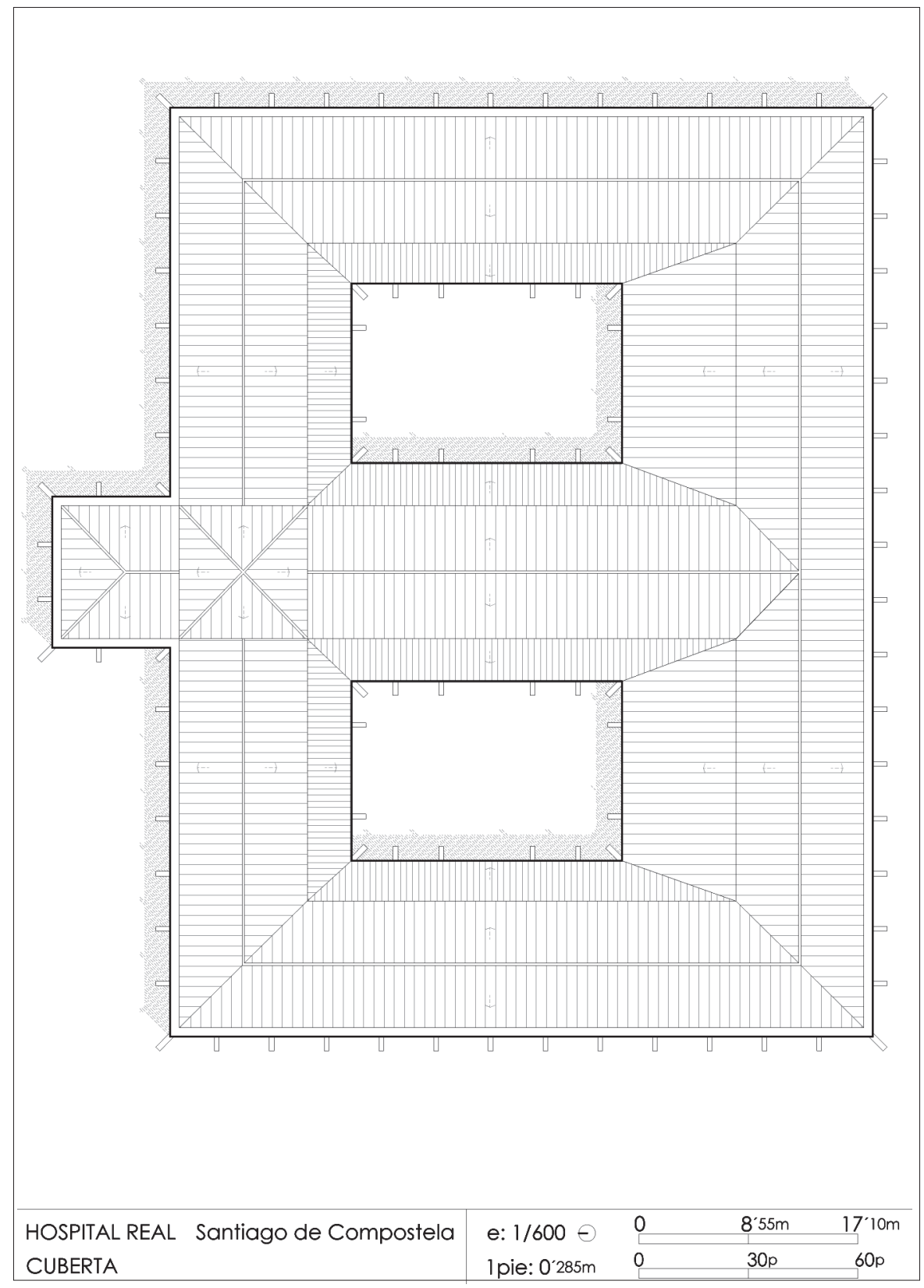

Fig. 3. Hospital Real. Planta cubierta. Plano propio. 
antigua vara de Toledo de $0,906 \mathrm{~cm}$., aunque sus sucesores no siguieron con este empeño. En 1347 será Alfonso XI quien instaure la vara de Burgos o vara real de Castilla de $0,836 \mathrm{~cm}$. como medida oficial del reino. Juan II en 1435 confirma de nuevo la medida toledana para la vara, pero la de Toledo nunca fue popular por tener un tamaño excesivo respecto al resto de las varas, con lo que sus reformas unificadoras fracasaron. Enrique IV y los Reyes Católicos presentaron poco interés en este tema; será Felipe II el que promulgue en 1567 el código conocido como "Nueva Recopilación", que intenta abarcar una vez más el caos legislativo existente promoviendo la vara de Castilla, que tuvo una general aplicación en todo el Nuevo Mundo y Filipinas, pero en la Península e islas, cuando en 1849 la reina Isabel promulga el Sistema Métrico Decimal, se contabilizan hasta veinte sistemas de medidas diferentes ${ }^{20}$.

Tres de esas veinte varas se utilizaban en Galicia oficialmente: la vara de Lugo de 0,855 m., la vara de A Coruña de 0,843 m., y la vara de Burgos o vara real de Castilla de $0,836 \mathrm{~m}$. en Pontevedra y en Ourense. Aunque comúnmente cada vara se utilizaba de manera oficial en su campo geográfico determinado, no eran exclusivas de cada zona, es decir, que estas tres varas coexistieron por toda Galicia en mayor o menor grado por diversas circunstancias, entre las que destacan la movilidad de los maestros en aquella época (gallegos, trasmeranos, portugueses...) y la estructura territorial de las diferentes Congregaciones, órdenes mendicantes, e incluso promotores de otra índole, que no se regían rígidamente por las reglas localistas.

El Hospital Real está sito en Santiago de Compostela, ciudad que prácticamente equidista del resto de las urbes gallegas, por lo tanto no es extraño que en ella encontremos indistintamente construcciones realizadas con cualquiera de las tres varas. A ello debemos sumarle la imponente presencia de la fábrica catedralicia, cuyo sistema de medición se basó en la vara de 0,974 m., medida Medieval obsoleta en el siglo XVI por su extrema longitud, aunque aún podemos rastrear sus vestigios métricos en obras compostelanas de esa época.

El estudio metrológico del Hospital Real se inició por varios cauces, donde destaca la medición in situ de la fábrica y la búsqueda de la vara utilizada en su proyección.

Resulta bastante difícil hoy día determinar exactamente el pie que se utilizó puesto que fueron varias las fases de construcción, derrumbes, desplomes, rehabilitaciones y modificaciones que sufrió el Hospital Real. Además en ciertos muros los estucos pueden llegar hasta los $10 \mathrm{~cm}$. de espesor. También debemos tener en cuenta que alguna de la poca documentación que existe sobre las dimensiones

\footnotetext{
${ }^{20}$ José Miguel Merino de CÁCERes, Metrología y composición en la arquitectura medieval española, Madrid, ETSAM, Departamento de Composición arquitectónica, 2002, págs. 22-32.
} 
de determinados elementos del hospital puede conducirnos a error. E incluso, si atendemos a elementos parciales de la fábrica, podríamos llegar a suponer (erróneamente) que se utilizaron varas diferentes para resolver partes de la edificación, lo cual tendría cierto sentido debido a la disparidad de procedencia de las cuadrillas que intervinieron en la obra y a su dilatado proceso de construcción y reconstrucción. Por si fuera poco, a todo ello debemos sumarle la gran reforma acaecida a mediados del siglo XX, a partir de la cual el Hospital Real pasó a formar parte de la red de Paradores del Estado, uso que aún conserva en la actualidad, y cuya reforma se realizó bajo el yugo del actual sistema métrico decimal, instaurado en España hace tan sólo 150 años, que se desvincula totalmente del sistema antropométrico de la vara de 3 pies utilizada hasta entonces. Por todos estos factores, la presente investigación metrológica se deberá tomar con la oportuna cautela.

En la medida de lo posible, lo que se pretende en esta fábrica no es transcribir exactamente las dimensiones que hoy en día existen de tal o cual parte del edificio, que pueden ser fruto de multitud de variables, sino que se omitirán dichas distorsiones para no desvirtuar el concepto global del edificio y así llegar a entenderlo más allá de las pequeñas variaciones acaecidas durante su vida, para poder profundizar en los conceptos que manejaba Egas.

Comprendiendo las limitaciones enumeradas anteriormente, hemos utilizado el método ensayo-error para aproximarnos a la fábrica paulatinamente hasta llegar a concluir que la medida que más concilia con todas las dimensiones es la de la vara de Lugo, de 0,855 m., cuyo pie mide 0,285 m. (1 p. =0,285 m.).

Tres han sido las pautas en las que nos hemos centrado en nuestro estudio metrológico para llegar a la conclusión de que dicha vara fue la oficial para la construcción hospitalicia: esta vara liga metrológicamente las dimensiones generales de la fábrica, las dimensiones de los claustros y las dimensiones de la capilla. Descartamos en las tomas de datos las dimensiones de los muros ya que su mayoría presentan espesores muy distorsionados debido a que prácticamente su totalidad fueron reconstruidos a lo largo de su historia. Tampoco nos pudimos basar en las referencias de algunos planos antiguos que se conservan con su escala antropométrica debido a que comúnmente dicha escala presenta cierta distorsión, ni tampoco en las escasas medidas que aparecen en alguna documentación, como en el Convenio entre el Hospital y la ciudad sobre la obra del patio cabe las puertas (atrio) o lonja ${ }^{21}$, que marcan $21 \mathrm{p}$. desde las paredes del hospital hacia la plaza mayor, y cuyas dimensiones reales exceden con holgura lo pactado en dicho documento (lo excederían incluso si se hubiera utilizado la vara catedralicia medieval).

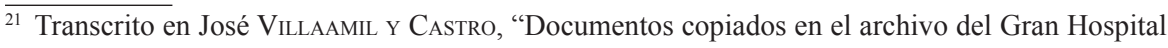
Real de Santiago", Galicia Histórica. Colección Diplomática, 1 (1901), págs. 586-587.
} 
Así pues, la traza global del Hospital Real presenta un esquema de planta latina que se inscribe en un rectángulo de proporción sesquitércia (4/3) (187,5 x 250 p.), del que tan solo sobresale la sacristía de la capilla hacia el Norte.

Aunque Hontañón a mediados del siglo XVI rehabilitó los lienzos de los patios, no existen indicios de que variase la distancia a ejes de las columnas, por lo tanto los patios primigenios también se insertaron en sendos rectángulos, donde la distancia entre ejes de arcadas es de 12,50 p., submúltiplo de números usados hasta la saciedad en el Medioevo para construcción de grandes edificios: 25 p., 50 p., 75p. y 100 p. Así pues los patios también presentan una relación en los corredores sesquitércia (75 x 100 p.), mientras que su razón a ejes de lienzos es sesquiáltera $(3 / 2)(50 \times 75 \text { p. })^{22}$.

Enrique y Antón Egas eran hijos de Egas Cueman y sobrinos de Hanequin de Bruselas, por lo tanto es lógico pensar que los tratados de arquitectura que circulaban en Centroeuropa a finales del siglo XV, de Matthäus Roritzer, Hans Schmuttermayer y Lorenz Lechler ${ }^{23}$, recogerían gran parte del saber que sus predecesores les transmitieron. En ellos, entre otras cosas, se habla de cómo se debía componer una iglesia, cuyas dimensiones generales, alturas y tamaño de los elementos principales se obtienen mediante relaciones aritméticas simples que derivan de una medida base: la luz del coro, a partir de la cual se obtiene otro módulo más pequeño: el espesor de la pared, que resultará 1/10 de la luz del coro $^{24}$. Lorenz Lechler especifica en su tratado, que para una iglesia de una sola nave, su luz ha de ser 30 p. mientras que sus muros tendrán 3 p., lo que nos da la relación $1 / 10$ citada anteriormente.

Esta regla se reproduce en la capilla del Hospital Real cuya luz del coro, que coincide con el ancho de la nave, mide $30 \mathrm{p}$. de ancho, mientras que el espesor de los muros es de 3 p. Así pues la concepción métrica de la capilla sigue las pautas aritméticas básicas de los tratados centroeuropeos (la nave transversal reduce ligeramente el ancho de 30 p., condicionada por el ajuste compositivo general, como así se desprende de los análisis planimétricos).

\footnotetext{
En el Reconocimiento de la casa del Hospital donde posó S.M. realizado en 1554 por el escribano Juan Nuño, se describen las dimensiones de los patios con 47 p. de largo y ancho. Estas medidas las damos por erróneas puesto que no hay ningún indicio que avale que los patios fueron cuadrados. Ni siquiera Villaamil y Castro, que trascribió dicha documentación, dibujó el esquema del proyecto de Egas con patios cuadrados, al igual que tampoco lo hizo Secundino Zuazo, Rosende Valdés, Pita Andrade o Vila Jato/Goy Diz. Todos entendieron que los patios primigenios fueron rectangulares. Transcrito en: José Villaamil y Castro, "Documentos copiados en...", pág. 596.

${ }^{23}$ Alberto Durero, De la medida, Jeanne Peiffer (ed.), Madrid, Akal, 2000, pág. 50.

${ }^{24}$ Santiago Huerta Fernández, "Las reglas estructurales del gótico tardío alemán" en Miguel Arenillas, Cristina Segura, Francisco Bueno, Santiago Huerta (eds.), Actas del Quinto Congreso Nacional de Historia de la Construcción, Burgos, 7-9 junio 2007, Madrid, Juan de Herrera, SedHC; CICCP; CEHOPU, 2007, págs. 519-532.
} 
Aun conociendo la gran distorsión que presentan los muros, se puede entrever que de forma genérica se dimensionaron los muros de carga con un espesor de 3 p., debido a su fácil manejo puesto que los 3 p. conforman la vara, que es el elemento de mesura elemental del que se valían los canteros a la hora de dimensionar y trabajar. Esta vara poseía varias muescas que ayudaban a dimensionar en obra a los canteros, entre las que destacan en primera instancia los pies y en un segundo orden los palmos y las pulgadas.

Tras lo visto, se podría entender que la aritmética es la verdadera generadora del proyecto, pero esto no es del todo cierto ya que es en su perfecta sintonía con las medidas ciertas $\sqrt{ } 2$ y la proporción áurea, donde se desarrolla el campo de trabajo y germen de todas las relaciones armónicas del edificio. Y es que existen ciertas relaciones aritméticas que concilian con dichas razones geométricas. En el caso particular que nos ocupa destacamos dos de ellas: $7 / 5(7 / 5=1,40 ; \sqrt{2}=1,41)$ y $5 / 3(5 / 3=1,66 ; \varnothing=1,62)$. Es bastante probable que la idea primigenia parta conceptualmente de las medidas ciertas, pero son las proporciones aritméticas las que se utilizan asiduamente en las fábricas debido a su fácil manejo ya que dotan a la puesta en obra de medidas racionales y exactas.

La razón pentatercia $(5 / 3)$, en sintonía con la proporción áurea, está dispuesta en el zaguán de entrada ( 30 x 48,5 p.), así como en la totalidad de la fábrica hasta la nave transversal de la capilla $(150 \times 250$ p.).

Por su parte, la medida cierta $\sqrt{ } 2(7 / 5)$ aparece en la fábrica combinando armónicamente un sistema escalar y otro proporcional. Esta razón parte de la base cuadrada de 75 p, a partir de ella la proporción $\sqrt{2}$ se conjuga basada en un sistema escalar, el cual en vez de agregar unidades de dicha razón como correspondería a la concepción islámica, prolifera en hábil superposición escalar dando como resultado una sucesión de dimensiones proporcionadas ( 75 x 106 p. - 106 x 150 p. - $150 \times 212$ p.) dentro de un edificio compacto, propio del Renacimiento. Estas medidas no son aleatorias sino que provienen de hallar la llamada Proporción Geométrica, Proporción Continua o Número Jámblico entre las distintas partes del Hospital. Dicha Proporción relaciona los elementos A-B-C en la ecuación $\mathrm{A} \times \mathrm{C}=\mathrm{B} \times \mathrm{B}$. Así pues la relación 75-106-150 se expresa en la ecuación $75 \times 150 \approx 106 \times 106$, de tal modo que 75 x 150=11250 es prácticamente igual a 106 x 106=11236. Lo mismo sucede con la relación 106-150-212 que se ex-

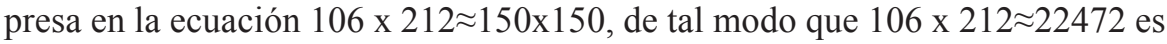
prácticamente igual a $150 \times 150=22500$.

Esta doble Proporción Continua también se puede expresar con las cuatro dimensiones utilizadas A-B-C-D, en la ecuación $\mathrm{A} \times \mathrm{D}=\mathrm{B} \times \mathrm{C}$, de tal forma que $75 \times 212=106 \times 150=15900$.

Por lo tanto, comprobamos como lo que en un principio parecía una mera aplicación de los tratados Centroeuropeos góticos, torna en su desglose métrico 


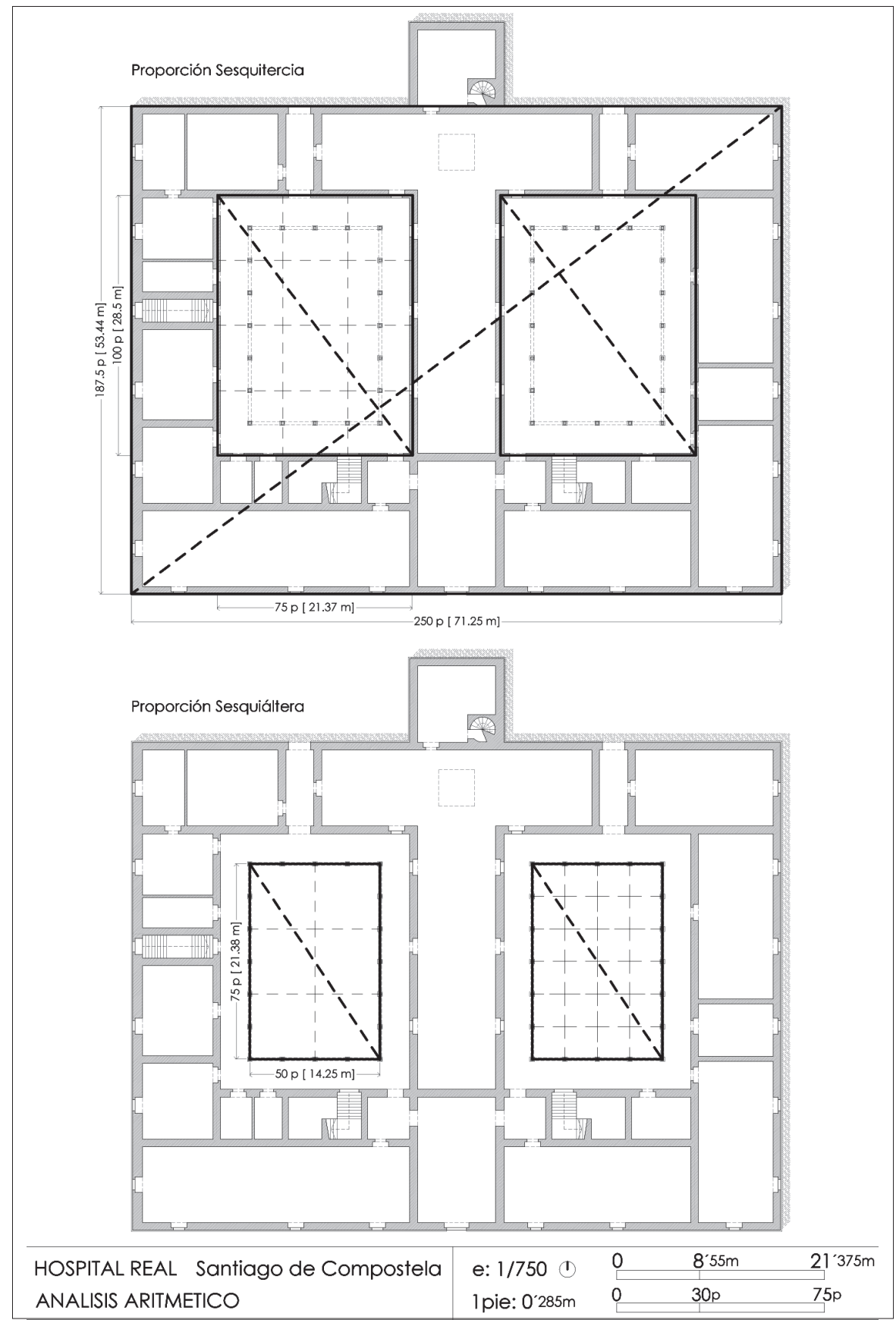

Fig. 4. Hospital Real, Análisis Aritmético. Plano propio. 


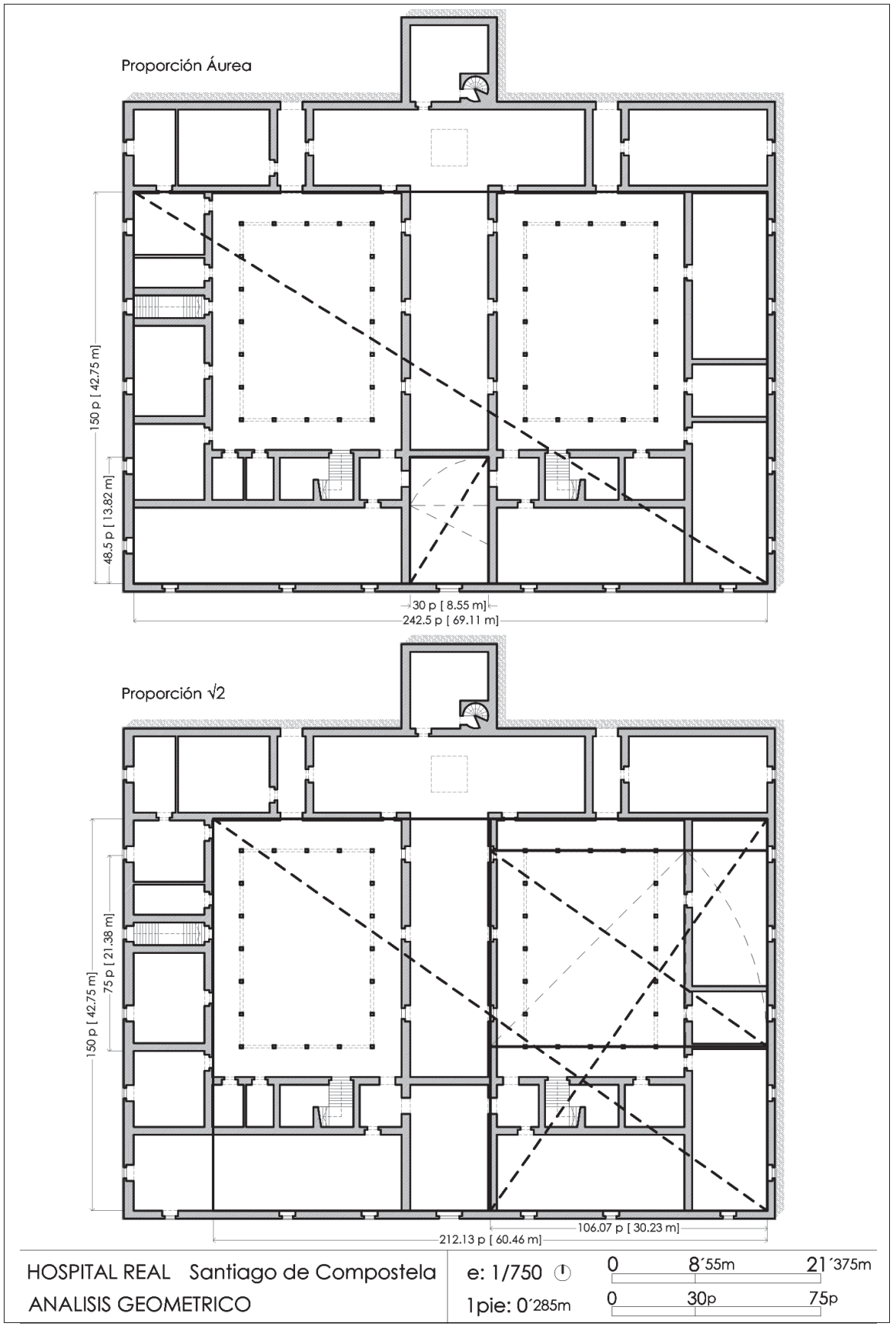

Fig. 5. Hospital Real, Análisis Geométrico. Plano propio. 
a conceptos más afines a los postulados humanistas. Ello se observa en mayor medida al enlazar la aplicación métrica de Egas en la fábrica respecto a la referencia contemporánea más notable: Alberti. Y es que en su ordenación taxonómica de la belleza de la arquitectura, su concinnitas procedía de tres elementos: numerus, finitio, collocatio, medir, proporcionar y colocar con cierta compostura, es decir, en base a la eurythmia.

El numerus nos aporta medida, y no solo de dimensiones, sino también de cantidades. En ambos casos este número puede además presentar un carácter simbólico, como cercioramos en las dimensiones y cantidades principales del Hospital.

Cada claustro presenta en su planta baja 3 x 5 columnas centrales, o contando las de las esquinas $5 \times 7$ columnas; todas ellas suman 20 columnas, mientras que en la planta alta el ritmo es binario por lo que el número de columnas es 40 , en total 60 columnas.

El 3, el 5, el 7 y el 40 son números de gran importancia para el cristianismo ya que se valían de ellos para transmitir ciertas ideas de su doctrina en aras de explicar el sentido Cósmico de la vida: el 3 representa la totalidad o unidad de la Trinidad, es el número divino; el 5 simboliza el puente entre lo terrestre y lo celeste, es el número del hombre; el 7 es el número de la perfección y el 40 nos habla de la celebración de la Cuaresma, período de reflexión y conversión espiritual a la espera de la Resurrección de Cristo.

Incluso la suma de las cifras de las que constan las principales dimensiones del Hospital nos vuelven a remitir a dichos números simbólicos: $250=2+5=7$; $187,5=1+8+7+5=21=2+1=3 ; 100=1,75=7+5=12=1+2=3 ; 50=5$.

Por último sobre el tema del numerus comprobamos como dichas dimensiones principales del Hospital se formularon en base a la combinación de los sistemas decimal $(1 \times 2 \times 5=10)$ y sexagesimal $(1 \times 2 \times 3=6): 250=2 \times 5 \times 5 \times 5 ; 100=2 \times 2 \times 5 \times 5$; $75=3 \times 5 \times 5 ; 50=2 \times 5 \times 5 ; 60=2 \times 2 \times 3 \times 5$, que son los sistemas básicos estructurantes de las medidas, gracias a los cuales se puede llegar a la harmonía y a la explicación numérica del universo ${ }^{25}$.

En cuanto a la finitio albertiana se vincula con la eurythmia, esto es con la proporción visualizada, hecha plástica, sentida. El número se hace línea y, en esa medida se cualifica. La eurythmia se basa en tres conceptos: en la armonía musical con la asimilación de las relaciones aritméticas, en la geometría de los cuerpos con la asimilación de las relaciones geométricas, y en la matemática con las mediocridades o medias, que procede de las anteriores. Entre dos extremos, sean cuales sean, cabe una media aritmética, una media geométrica y una media

\footnotetext{
${ }^{25}$ Víctor Grande Nieto, Proceso Metodológico y Compositivo del Renacimiento en Galicia, 14991657, tesis doctoral inédita, A Coruña, UDC, 2014, págs. 108-109.
} 
armónica, que aseguran el control de dos relaciones binarias ${ }^{26}$. No redundaremos en estos conceptos al haber comprobado con anterioridad como Egas ha utilizado dichas relaciones aritméticas, geométricas y las medias (en este caso la Proporción Continua, que es una media geométrica) para componer planimétricamente el Hospital Real.

Por último, la collocatio es la disposición de las partes en el conjunto, la co-locación de los llenos y vacíos. Este concepto ciertamente no se puede cuantificar, no es mesurable, por lo tanto es difícil de entender; pero al contrario es fácil de ver puesto que es un concepto sensitivo y perceptual. Está íntimamente relacionado con las anteriores, puesto que una buena finitio se consuma en una buena collocatio ${ }^{27}$, así pues al ver la planimetría del Hospital (al igual ocurre con sus alturas y fachadas que analizaremos en su momento), aún sí desconociésemos sus proporciones seguiríamos percibiendo la eurythmia en sus trazos ya que la conccinitas no es simplemente una mera cuestión dimensional.

RECONOCIMIENTO PERICIAL DE RODRIGO GIL DE HONTAÑÓN. TIEMPOS VERBALES

El peritaje de Rodrigo Gil de Hontañón realizado en $1555^{28}$ nos presenta una gran dosis de incertidumbre, puesto que además de no conocer el texto íntegro, entendemos que diverge de lo que finalmente se ha realizado.

Presentamos en estas líneas una hipótesis novedosa sobre la reconstrucción hontañoniana del Hospital Real respecto a los monográficos que más han profundizado en ello: los estudios de Rosende Valdés ${ }^{29}$ y Vila Jato y Goy Diz ${ }^{30}$, puesto que ambos interpretan que Hontañón, en el peritaje que realizó sobre la fábrica áulica, quería modificar todo aquello que estaba criticando, dando por hecho que el texaroz o la cornisa de la fachada se substituyó y que los patios son de nuevo diseño, aprovechando de los primigenios tan solo ciertos elementos de ornato.

En este artículo planteamos una visión completamente diferente del peritaje, en donde entendemos que en primera instancia Hontañón enumera toda una batería de fallos o errores proyectuales para, seguidamente proponer las soluciones más acordes según la fábrica existente, ya que, por entonces, era notoria la parquedad

\footnotetext{
${ }^{26}$ Joaquín ARnau Amo, La teoría de..., vol. II, pág. 140.

27 Joaquín Arnau Amo, La teoría de..., vol. II, pág. 143.

${ }^{28}$ Transcrito en José VillaAmil y CASTRo, "Documentos copiados en...", págs. 602-606. Transcrito en A. Rosende Valdés, El Grande y..., págs. 294-295.

${ }^{29}$ A. Rosende Valdés, El Grande $y \ldots$.

${ }^{30}$ María Dolores Vila Jato; Ana Goy Diz, "Textos generales" en María Dolores Vila Jato (coord.), Parador "dos Reis Católicos", Santiago de Compostela, un hotel con quinientos años, el más antiguo de Europa, Madrid, Paradores de Turismo de España, 1999.
} 
de las arcas del Hospital Real, como así constata un documento fechado en 1561, que dice:

acordaron y mandaron que en ese dicho hospital no aya hobras mas de que ... se entienda en adreçar e acabar los corredores que están derrocados y començados a hazer, y que la demás obra çese por el presente atento a la necesidad del dicho hospital y lo poco que tiene para poder hazer mas ${ }^{31}$.

El peritaje de Hontañón está bien estructurado, no mezcla en su inspección partes del edificio, por un lado está la fachada y por otro los patios (al final también aparecen escuetos párrafos sobre la capilla, campanario y fuente, de relevancia secundaria).

Tanto el análisis que realiza de la fachada como el de los patios, se pueden estructurar a su vez cada uno en otras dos partes claramente diferenciadas gracias a los tiempos verbales que emplea, así pues Hontañón utiliza en un primer momento casi todos los tiempos verbales en pasado (alguno en presente), mientras que al final de cada ente analizado, emplea la mayoría de los tiempos en futuro (alguno en presente).

Entendemos pues que el cambio en la forma de hilvanar el discurso es claro: Rodrigo Gil de Hontañón utiliza tiempos verbales en pasado cuando se refiere a la obra construida por Egas y que según él no se debería haber hecho así. Hontañón utiliza tiempos verbales en pasado para argumentar sus críticas, dando las claves de las patologías y lesiones del edificio, y marcando además como hubiese él solucionado el proyecto en un inicio.

Pero ciertamente en 1555 ya no hay fondos para realizar un nuevo claustro ni para acometer profundas reformas, por lo que la encomienda al maestro de Rascafría se limitaba a remediar el colapso del edificio con el menor gasto posible. Así pues cuando aporta soluciones en su peritaje, lo hace utilizando tiempos verbales en futuro.

Fragmentos del peritaje:

FACHADA

$1^{\text {a }}$ Parte (verbos en pasado y presente). Se incluye el primer párrafo:

...parece se hizo inadvertidamente...este texaroz fue labor ynadvertida impropia voluntaria y profana...

\footnotetext{
${ }_{31}$ AHUS, Hospital Real, Cabildos, Visitas, Juntas y Ministros, no 205, fol. 96v. Transcrito en
} A. Rosende Valdés, El Grande y..., pág. 295. 
$2^{\mathrm{a}}$ Parte (verbos en presente y futuro). Se incluyen los últimos cinco párrafos:

...me parece que para el reparo y reformacion de las dichas paredes...que solamente se deshagan los maderamientos altos...deuria ser pieça perpianada... my parecer y boto seria que...se podran echar sus tirantes de hierro...

PATIOS

$1^{\text {a }}$ Parte (verbos en pasado y presente). Se incluyen los dos primeros párrafos:

...para ser firmes los dichos arcos baxos y altos avian de ser...debieran ser las colunas primeras mucho mas corpulentas...encima de la cornixa avia de hacerse su farda ... avia de haver encima la cornixa los suelos de los andenes de los corredores...

$2^{\mathrm{a}}$ Parte (verbos en presente y futuro). Se incluyen los últimos dos párrafos:

...conbiene hacer ocho arcos en cada patio...se llaman arbotantes y anse de emalmerar en sus pilares...en las paredes se ha de ronper como se pueda...de mi parecer se quitaría toda aquella labor superflua y pessada...

Desglosaremos nuestras conclusiones al respecto en los apartados sucesivos.

\section{FACHADA}

El alzado meridional es el frons aedis del Hospital Real, que representa su imagen hacia la ciudad (hoy distorsionada por los añadidos posteriores). Esta fachada transmite una imagen poderosa y unitaria, que proviene de los palacios del Quattrocento italiano, cuyo esquema de edificio era una gran masa cúbica, aislada del resto de la ciudad, autosuficiente y polifuncional, en el que predominaba la horizontalidad de su fachada almohadillada amparada en una gran cornisa.

El arquetipo pudo ser la Banca Medicea de Milán, realizada por Michelozzo entre 1455-1460, hoy destruida pero la cual aparece en el tratado de Filarete. De la fachada milanesa derivaron otras como el palacio de Orsini en Nola o el palacio Sanseverino en Nápoles. Justamente la de Orsini se antoja como el modelo directo del palacio de Medinaceli en Cogolludo, el cual se encuentra cercano a Toledo, lugar donde residía Egas. En la península, además del palacio de Medinacelli, también siguen este esquema la Casa de los Momos en Zamora, el palacio de los duques del Infantado en Guadalajara y el palacio de los duques en Gandía ${ }^{32}$.

Estos modelos de fachadas desarrollaron un esquema métrico en base al doble de la proporción áurea, teniendo de longitud unos 150p (la fachada de la Banca

\footnotetext{
32 Federico IBORRA BeRnARD, "El problema de las fachadas asimétricas en la arquitectura residencial del tardogótico castellano", en Begoña Alonso Ruiz (ed.), La arquitectura tardogótica castellana. Entre Europa y América, Madrid, Silex, 2011, págs. 339-352.
} 


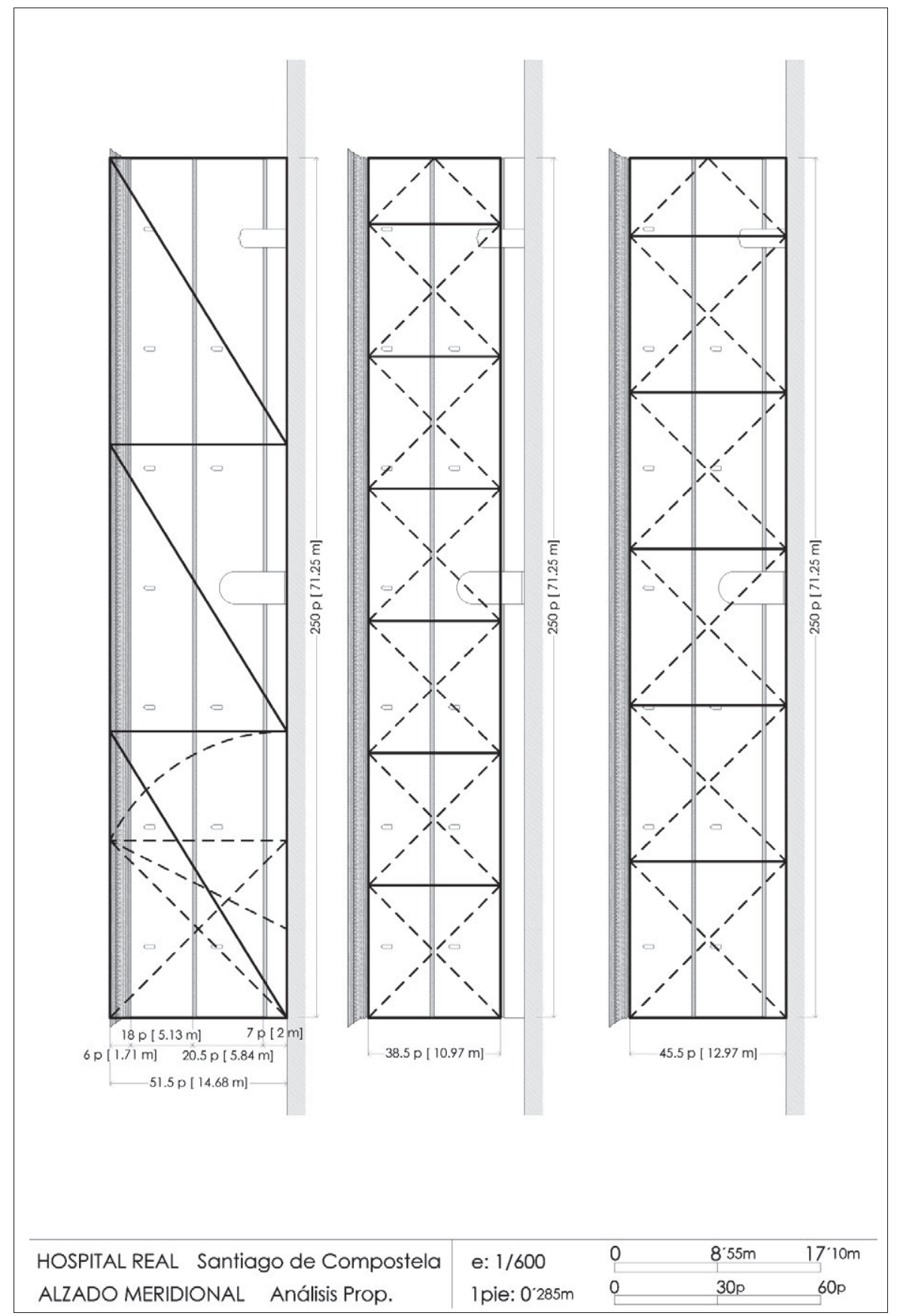

Fig. 6. Hospital Real, Alzado Meridional. Análisis proporcional. Plano propio. 
Medicea mide 87,5 x 27 brazas florentinas, que al uso serían unos 147 x 45 p.). Es seguro que Egas conoció alguno de estos modelos, y aplicó sus cualidades estéticas y compositivas a la fachada compostelana, ya que la fachada del Hospital Real, de 250 p. de longitud, presenta múltiples proporciones entre las que destaca la triple proporción áurea que conforma la totalidad de la misma (250 x 51,5 p.), dando un paso más en la evolución de este tipo.

También encontramos otras relaciones que configuran la posición y altura de los elementos arquitectónicos que conforman el lienzo de la fachada meridional, así pues sin contar la cornisa, la longitud de la fachada es 5,5 veces su altura ( 250 x 45,5 p.), y descontando también el zócalo, dicha relación de la longitud de fachada aumenta hasta las 6,5 veces su altura $(250 \times 38,5$ p.).

Estas relaciones de la fachada nos conducen nuevamente al concepto albertiano de concinnitas, que desarrollamos en el apartado de la métrica. Lamentablemente para nuestro propósito, la fachada experimentó importantes cambios a lo largo de los siglos: la portada principal, la gran balconada y los innumerables vanos abiertos, por lo que resulta imposible en la actualidad saber cuál era la disposición original de sus vanos (suponemos que serían pequeños vanos esbeltos con remate conopial, como varios de los dispuestos en la fachada lateral), lo que a fin de cuentas nos ayudaría a confirmar o desmentir si Egas perseguía también en el frons aedis del Hospital Real una vera collocatio, como así indican la disposición del resto de los elementos primigenios que aún se conservan de la fachada meridional.

\section{INTERVENCIÓN DE RODRIGO GIL DE HONTAÑÓN EN LA FACHADA}

La fachada hospitalaria presenta una cornisa muy pronunciada, de gran carga decorativa y amplio vuelo que remarca la horizontalidad del edificio. Todo ello justamente lo criticaba Hontañón en su peritaje: parece se hizo ynadvertidamente porque su buelo y alto en extrema cantidad es demassiado y excesibo segun el grueso que las flacas paredes.

No hay más que recordar algunos de sus edificios civiles como el Palacio de Monterrey o el de los Guzmanes para entender su postura, que muestra sin tapujos unas líneas más abajo: parece henano y baxo el edificio del texaroz abaxo y no aviendo otra architectura ni torres ni estribos ni otra guarnicion en las dichas paredes por via de ornato.

Puesto que no va a poder proyectar unas torres en las esquinas, como a buen seguro hubiese deseado, se limita a sanear la fachada, desmontándola y rehaciéndola con unos muros más estables mediante el grapado transversal con hierros y con perpiaños.

También dice: 
...my parecer y boto seria que... el texaroz todo se desasentase y el mucho alto y buelo que tiene fuera de proposito y fuera de toda artes da mente quedase en vna cornixa de muy buenas molduras al romano muy repartidas y ordenadas de media vara de buelo y otro tanto de alto... sus gargolas sean aviertas y no vuelen fuera de la salida de la cornixa ninguna cosa sino... sus caños de plomo o laton que salgan fuera de la cornixa vna bara de medir...

Este fragmento resulta sumamente interesante, puesto que propone cambiar la imponente cornisa por otra al romano... de media vara de buelo y otro tanto de alto y substituir las gargolas mal entalladas por caños de plomo o laton.

Dicho esto, rastreamos la obra en busca de verificar estos cambios propuestos, y comprobamos visualmente que ni la imponente cornisa se trocó por otra a lo romano, ni las gárgolas mal entalladas se substituyeron por simples caños de plomo o latón. Pero si quedase algún resquicio a la posible interpretación que Hontañón hace sobre la cornisa a lo romano, analizando antropométricamente la fachada despejamos cualquier margen para la incertidumbre, y es que a través de los estudios que hemos realizado en esta fábrica, podemos afirmar que se construyó en base a un pie de 28,50 cm., en donde la cornisa existente presenta una dimensión en altura justamente de 2 varas, muy distante a la media vara que proponía Hontañón (si trasladamos estos datos al Sistema Métrico Decimal, comprobamos que la dimensión existente es de 1,71 m., mientras que la dimensión que propone Hontañón era tan solo de $0,43 \mathrm{~m}$.), por lo tanto resulta evidente que, después de desmontar y sanear la fachada estabilizando y solidarizando los esfuerzos mediante el grapado de las piedras, se reutilizó la cornisa primigenia que Egas había proyectado ${ }^{33}$.

\section{HiPÓTESIS SOBRE LOS PATIOS}

Si analizásemos el peritaje desde la perspectiva de entender que Gil de Hontañón hubiese querido modificar todo aquello que critica -es decir, cuando utiliza los tiempos verbales en pasado-, veríamos que no se habrían seguido las trazas que Gil de Hontañón tendría proyectadas para los patios, lo que a su vez y del

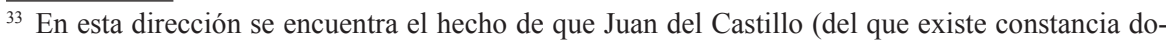
cumental que trabajó en el Hospital Real compostelano) realizó la cornisa de la capilla mayor de la Catedral de Braga en torno al año 1509, la cual deriva de la del Hospital Real ya que existen grandes similitudes entre ambas: en la cornisa portuguesa utiliza de forma similar los arquillos ciegos y las cadenas, presenta unos modelos de gárgolas en clara sintonía con los del Hospital y además introduce en la cornisa las rosas cuadrifolias.
} 
mismo modo, implicaría que lo existente hoy en día corresponde en mayor medida a aquello que inicialmente trazó Egas.

Así pues, de los párrafos en los que Hontañón utilizó los tiempos verbales en pasado, podemos extraer fragmentos como:

CIMENTACIÓN

...para ser firmes los dichos arcos baxos y altos avian de ser sacados sus fundamentos y cimientos de su çavia a la larga que ansi fuere maciço lo hueco de los arcos como donde cargan las columnas....

En este fragmento Hontañón critica que las columnas se asentasen en zapatas aisladas y no en una cimentación corrida, pero a tenor de las obras de restauración realizadas en 1950 para convertir el Hospital Real en Parador, se pudo comprobar que las zapatas de las columnas no se modificaron sino que se mantuvieron aisladas.

LIENZOS

Más revelador resulta aún el fragmento de los lienzos:

...y debieran ser las columnas primeras mucho mas corpulentas $y$ de mas grueso ansi para sufrir el peso y carga y ser firmes como para tener proporción en su grueso según su alto...los arcos altos están fuera de traça y raçon ansi por salir fuera de las líneas sobre falso como por ser muy mas gruesos y pesados los pilares altos que no los baxos como por estar cargados sobre los huecos de los arcos baxos...

A la vista está que todos los inconvenientes que enumera Hontañón en su informe se mantuvieron en la fábrica actual: el ritmo binario en la planta alta, las columnas superiores siguen a ser mucho más gruesas que las inferiores, y las pilastras superiores sobresalen de la plomada que marcan las columnas inferiores, es decir, que la pilastra superior sobresale de la superficie inferior que recibe las cargas, provocando así una tensión excéntrica en una fábrica pétrea que se resiente de sobremanera cuando las cargas no actúan a compresión.

Por lo tanto, aunque existe la idea generalizada de que en el informe Gil de Hontañón muestra un ambicioso programa a la hora de proponer unos patios completamente nuevos, nuestra impresión es que utiliza tiempos verbales en pasado solamente para criticar el proyecto existente y argumentar como lo hubiera hecho él en 1499, es decir, cuando dice: debieran ser las columnas no está proponiendo que "deberían ser" en un futuro, sino que simplemente está criticando que se hicieron mal en el pasado. 


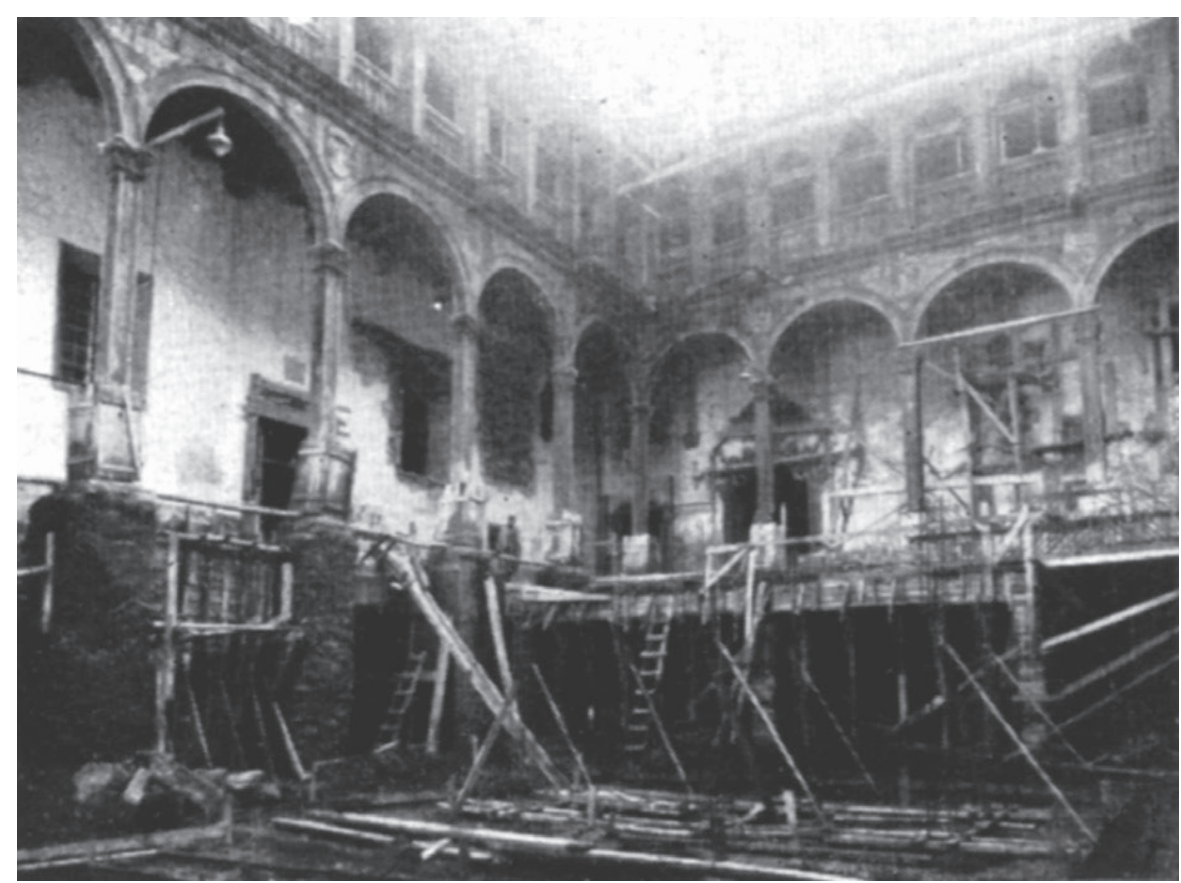

Fig. 7. Fotografía de las obras para Parador en 1950. Revista Nacional de Arquitectura, Madrid, año XIV, 156 (1954), pág. 8.

Así pues, luego de criticar con dureza la fábrica, plantea unas soluciones bastante económicas (expresadas con tiempos verbales en futuro) en las que aprovecha al máximo posible el patio primigenio, algo en consonancia con la situación económica que atravesaba el Hospital Real.

En los estudios recientes ha habido cierta controversia sobre el uso de la piedra de Ançá en los patios de Egas, también llamada piedra de Lioz o piedra blanca de Coimbra. Esta piedra es óptima para desarrollar sobre ella elementos decorativos puesto que su maleabilidad permite trabajarla como si fuera madera, por ello se trajo desde Coimbra a Padrón en barcos, para utilizarla en los elementos decorativos más refinados, como en los cuatro pilares calados de gran talla realizados en el crucero de la capilla. En el análisis pormenorizado de los patios, desglosaremos la posible utilización de la piedra de Ançá:

PISO INFERIOR

Se podría argumentar que todo el cuerpo inferior es obra nueva, puesto que se modifican las arcadas inferiores introduciendo unos arcos que atan los lienzos al muro del corredor y dichas arcadas presentan sus molduras en consonancia con 
las columnas que los soportan, además las enjutas fueron realizadas de nuevo, conservando tan sólo los escudos y armas reales (realizadas en dicha piedra), y si a ello le sumamos que según Vila Jato y Goy Diz ${ }^{34}$ las columnas y arcos primigenios eran de piedra de Ançá, deberíamos concluir que todo el cuerpo inferior es obra nueva.

Pero esta afirmación se contradice con las citas de Rosende Valdés, donde transcribe que Bartolomé de Rosende es autor de quatro salmeres de pyedra de grano que faltaban para los patios, y que Juan de Lemos extrae grano para arcos e pilares e entablamiento e antepechos e encoronamiento del patio de çima al igual que toda la pedrerya de grano que se avia de sacar e coger de la cantera ...para la tercia parte de la obra del patio bajo y la pedrería del patio de çima ${ }^{35}$.

La piedra de grano se le llama al granito, que es el material con el que están hechos todos los elementos que se nombra en los contratos de obra anteriores. A ello debemos unirle varios argumentos, y es que en lo sustancial, las columnas de la planta inferior son estrechas y esbeltas, objeto que criticaba Hontañón en su informe, como ya hemos visto. En ese mismo informe Hontañón también critica la piedra de Ançá que conforma los pilares calados de la capilla, ya que es corruptible ... y cria salitre y... salta pero nada dice de la piedra del patio, por lo que si fuese también piedra blanca, sería lógico que la criticase del mismo modo que hizo en la capilla. Y también se da el hecho de que los capiteles presentan grandes similitudes con los del Codex Escurialensis o el Tratado de Sagredo ${ }^{36}$, lo cual a su vez implica que si fuesen realizados hacia el 1560 tendrían cierto anacronismo; y es que a mediados del siglo XVI el Tratado de Serlio va a adquirir gran popularidad en España, cuyos capiteles compuestos se hallan en consonancia con los modelos del orden que expone Hontañón en su Tratado ${ }^{37}$ y que ciertamente difieren de los del Hospital Real por la ausencia de una gran carga figurativa

\footnotetext{
${ }^{34}$ M. D Vila Jato y A. Goy Diz, Parador dos Reis..., pág. 70.

35 AGS, Contaduría Mayor, Primera época, Legajo 217; 25, 47 y 57, respectivamente. Transcrito en A. Rosende ValdÉs, El Grande y..., pág. 70.

${ }^{36}$ Margarita Fernández Gómez, Codex Escurialensis 28-II-12, Libro de dibujos o antigüedades, Murcia, Patrimonio Nacional, 2000. Diego SAgredo, Medidas del romano, Toledo, Remón de Petras, 1526. El Codex Escuarialensis, de Domenico Ghilardaio ha sido elaborado mediante dibujos realizados en Roma entre los años 1480 y 1500 . Medidas del Romano, de Diego de Sagredo, ha sido elaborado mediante dibujos realizados en Florencia y Roma entre los años 1518 y 1521, y los recopilados en la península hasta 1526. Ambos libros presentan un lenguaje arquitectónico con gran carga ornamental, en los que apenas tiene cabida el estudio de su sintaxis.

37 Simón García, Compendio de architectura y simetría de los templos: conforme a la medida del cuerpo humano con algunas demostraciones de geometría, año de 1681, Valladolid, Colegio de Arquitectos de Valladolid, 1991.
} 
(recordamos que Casaseca Casaseca definió la obra realizada en esta época por Hontañón como purista).

Todos estos puntos hacen difícil constatar que los patios de Egas hayan sido construidos en su totalidad en piedra de Ançá. Entendemos más probable que dicha piedra haya sido dispuesta tan sólo en las enjutas de las arcadas ya que por su fácil trabajabilidad daba respuesta a la parte más decorativa de los lienzos, como así aún constatan varios escudos que se reaprovecharon en 1560, pero el resto del lienzo primigenio habría sido realizado en granito, incorporando Francisco de Juli los arcos arbotantes que atan los lienzos a los muros del corredor.

\section{ENTABLAMENTO}

En dos contratos de la obra de $\operatorname{Egas}^{38}$ se dice que se labraron 170 varas de granito para el entablamento de los patios, y que se realizaron 32 gárgolas que no estaban dispuestas en la traza inicial. Las dimensiones y el material del entablamento coinciden con lo existente, al igual que el número de gárgolas dispuestas en ambos patios. Ahora bien, las gárgolas están ubicadas en el entablamento intermedio, algo extraño puesto que éstas se presentan horadadas para evacuar las aguas y por lo tanto tuvieron una indudable función constructiva; por ello es probable que Hontañón, con la intención de aligerar el peso superior, desplazase las gárgolas al entablamento inferior. Este cambio podría ser influencia del vecino Colegio de Fonseca ya que su patio presenta gárgolas sin horadar en el entablamento intermedio con un único fin decorativo (dicho argumento cobra fuerza al ser probable que el lienzo superior del patio colegial lo halla trazado Hontañón entre 1538-1540).

Destacamos de los contratos del entablamento dos cosas: por un lado el material contratado y empleado en 1510 fue el granito y no la piedra de Ançá; y por otro es notorio que la decoración de los entablamentos del patio guarda vínculos evidentes con la gran cornisa exterior, cuya autoría de Egas ya hemos constatado anteriormente.

PISO SUPERIOR

Los estudios del Hospital más relevantes han postulado su discurso otorgándole la autoría del claustro a Hontañón, pero a la vez todos, en mayor o menor grado, han considerado que ciertos elementos decorativos como las rosas, las bolas, la cruz de Jerusalén y el balaustre (este último con más reservas) probablemente hayan sido reutilizados del claustro primigenio.

Intencionalidad no les falta, puesto que estos motivos decorativos son perfectamente adscribibles al taller de Egas, ya que también los encontramos en San

\footnotetext{
${ }_{38}$ AHUS, Hospital Real, Escrituras, núm. 94 (1509-1513), fol. 21v.-22, fol. 25, respectivamente. Transcrito en A. Rosende Valdés, El Grande y..., pág. 265.
} 
Juan de los Reyes: la cruz de Jerusalén aparece dispuesta en las enjutas de varias portadas, las bolas y rosas cuadrifolias aparecen revistiendo las molduras de los arcos; y el mismo modelo de balaustre aparece en el piso superior del claustro toledano, aunque en este caso se presenta calado.

Existe además la referencia documental del Hospital Real en 1509 donde se cita que se hagan los patios con buena moldura e rosas e buelas... (buelas=bolas).

Si todos estos elementos decorativos utilizados en el piso superior no presentan demasiada controversia para adscribirlos al taller de Egas, tampoco debería presentar incertidumbre el otorgarle la autoría de la fábrica, puesto que si bien el balaustre responde a una pieza independiente, y el conjunto de arcos y enjutas se resuelven también con dos piezas independientes del resto de la fábrica, los otros elementos constructivos, es decir: las jambas, el dintel, el antepecho y las pilastras, forman un ente indisoluble y continuo al asentarse en las mismas hiladas sin producirse cortes de cantería entre los distintos elementos, pudiendo una sola pieza pétrea formar a la vez parte de la pilastra, de la jamba y del antepecho.

Por ello no existen los suficientes elementos diferenciados constructivamente que nos permitan seguir la hipótesis de que el claustro haya sido realizado ex-novo por Hontañón reutilizando elementos del claustro primigenio de Egas, sino que entendemos que todo responde a un mismo momento constructivo, el de principios del siglo XVI.

CORONACIÓN

de mi parecer se quitaría toda aquella labor superflua y pessada $y$ perjudicial de los coronamientos y remates ansi por ser flacas y deviles las columnas primeras sobre que carga todo el edificio como por evitar el peligro de los grandes ayres... hacerse ya a la manera que esta en el colegio del Arzobispo en Salamanca que es cobrir los arcos en tejado y disimular las tejas con una pequeña guarnición saliendo fuera las bocas de las canales de plomo.

Estas modificaciones, en las que utiliza los tiempos verbales en futuro, sí se llevaron a cabo y hoy día no existe coronamiento o crestería de ningún tipo y se evacúa el agua con canales de plomo (y no con gárgolas).

Resulta sumamente interesante e incluso concluyente el hecho de que Hontañón diga que quitaría el coronamiento del patio por ser flacas y deviles las columnas primeras, y es que si pretendiera cambiar las columnas inferiores por otras mas corpulentas y de mas grueso como se dice en los párrafos donde utiliza 


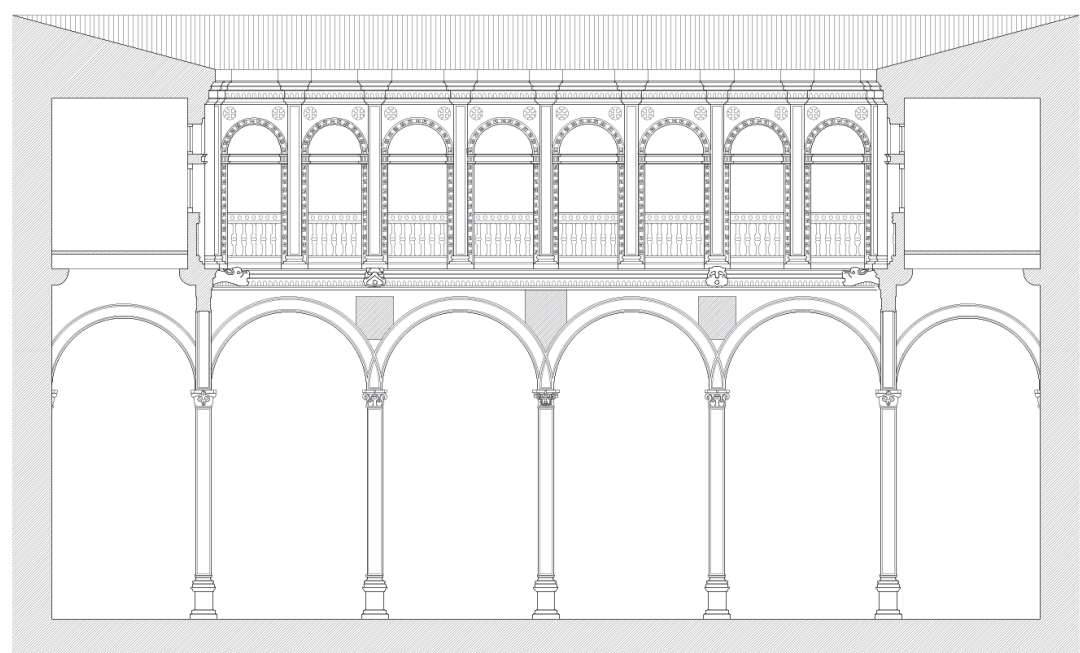

Patio Acłual. Gil de Hontañón

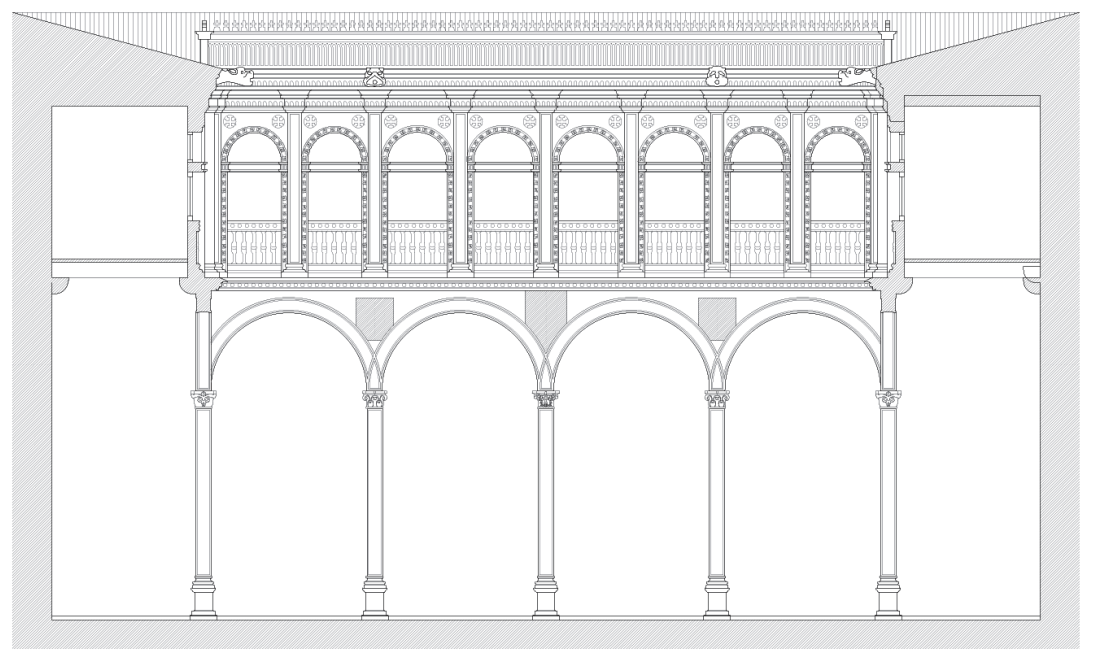

Hipótesis Patio Egas

\begin{tabular}{|c|c|c|c|c|}
\hline HOSPITAL REAL Santiago de Compostela & e: $1 / 200$ & 0 & $285 \mathrm{~m}$ & $5^{5} 70 \mathrm{~m}$ \\
\hline PATIO ACTUAL - HIPÓTESIS PATIO EGAS & 1pie: $0 ` 285 \mathrm{~m}$ & 0 & $10 p$ & $20 p$ \\
\hline
\end{tabular}

Fig. 8. Patio actual- Hipótesis patio Egas. Plano propio. 
tiempos verbales en pasado, no tendría sentido que justificase retirar la crestería debido a los pilares flacos, puesto que estos pilares ya no tendrían lugar en su nuevo proyecto.

Ante la parquedad económica que sufrían en ese momento las arcas del Hospital, los administradores decidieron emprender unas reformas de emergencia por el inminente colapso total de la fábrica y para ello llamaron a Hontañón, que no dudó en criticar el proyecto y construcción de Egas (utilizando en el peritaje los tiempos verbales en pasado), pero que se tuvo que adecuar a lo existente, sanearlo y estabilizarlo de la forma más económica posible (utilizando en el peritaje los tiempos verbales en futuro), introduciendo por lo tanto pequeñas variaciones que atendieron al carácter estructural del edificio (como son el retirar los coronamientos e introducir los arcos arbotantes), pero manteniendo en buen grado la sintonía con construido por Egas a comienzos del siglo XVI.

Los administradores le hicieron caso en todo lo que propuso Hontañón respecto a los patios. No ocurrió lo mismo en su propuesta sobre la reducción drástica de la altura y vuelo de la cornisa de la fachada, debido probablemente al sobrecosto que implicaría la realización de una nueva cornisa por lo que finalmente se reutilizó la existente, algo que en las décadas venideras les acarrearía de nuevo serios problemas de estabilidad.

En cuanto a la hipotética traza de los patios de Egas, no nos prodigaremos mucho por ser planteamientos intencionales más que análisis concluyentes, aunque tendemos a postularnos en que habrán seguido planteamientos encaminados a una correcta conccinitas, al igual que en el resto de la fábrica.

A partir de las dimensiones que manejamos: de 75 x $50 \mathrm{p}$. en planta con 12,5 p. a ejes de pilares, añadimos las supuestas dimensiones en altura: 25 p. el cuerpo inferior y $15,25 \mathrm{p}$. el cuerpo superior, sobre el que se asentaría una crestería que tendría en torno a la vara de $3 \mathrm{p}$.

Además de los numerus, ya comentados en el apartado métrico, comprobamos la disposición de la finitio en los patios.

En cuanto a las relaciones aritméticas: globalmente los patios se inscriben en un rectángulo, por lo que se presentan relaciones diferenciadas cada dos lienzos: los lienzos Norte y Sur tienen una relación sesquicuarta (40,25 x 50 p.), mientras que los lienzos Este y Oeste su relación es 13/7 (75 x 40,25 p.). Particularmente aparece la razón dupla en el plano inferior $(25$ x 12,5 p.) y una hipotética relación sesquiáltera entre ambas plantas contando la crestería ( $25 \times 18,75$ p.).

En cuanto a las relaciones geométricas: encontramos varias dimensiones superficiales que articulan el cuerpo inferior en base a las medidas ciertas $\sqrt{2}, \sqrt{3}$ y proporción áurea. Esta última incluso aparece en la relación lineal entre la altura de las dos plantas del lienzo ( 25 x 15,25 p.). 

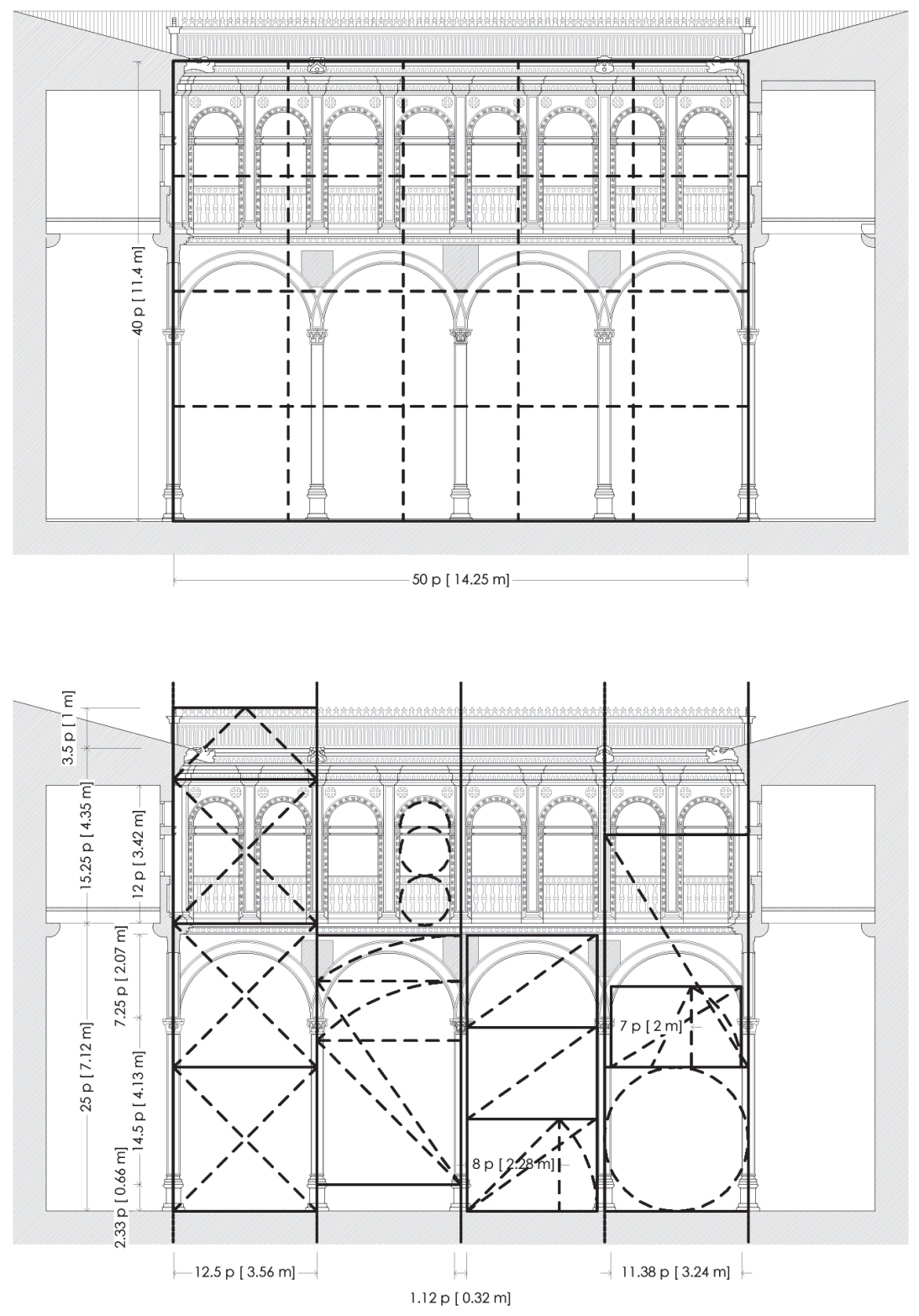

\begin{tabular}{|c|c|c|c|c|}
\hline HOSPITAL REAL Santiago de Compostela & e: $1 / 200$ & 0 & $285 \mathrm{~m}$ & $570 \mathrm{~m}$ \\
\hline HIPÓTESIS PATIO EGAS Análisis Prop. & 1 pie: $0 ` 285 \mathrm{~m}$ & 0 & $10 p$ & 20p \\
\hline
\end{tabular}

Fig. 9. Hipótesis patio Egas. Análisis proporcional. Plano propio. 
En cuanto a las relaciones medias encontramos dos: la media geométrica o Número de Jámblico resultante de las alturas de los cuerpos de los lienzos $15,25 / 25 / 40,25$, tal que $\mathrm{AxC}=\mathrm{BxB}$, es decir $15,24 \times 40,25 \approx 25 \times 25$. Y la media armónica resultante de las dimensiones en planta de los lienzos y su altura bajo la cornisa: $37 / 50 / 75$, tal que $\mathrm{B}-\mathrm{A} / \mathrm{A}=\mathrm{C}-\mathrm{B} / \mathrm{C}$, es $\operatorname{decir} 50-37 / 37 \approx 75-50 / 75$.

\section{HiPÓTESIS DE LA AMPLIACIÓN DEL HOSPITAL}

La ampliación del hospital consta ya operativa en 1527, pero a diferencia del edificio primigenio, los patios y estructura interior se materializaron en madera mientras que su exterior se dispuso en piedra, probablemente, por no disponer de los fondos necesarios para acometer toda la obra en cantería; pero puesto que querían acoger nuevas funciones necesitaban ampliar su capacidad y lo hicieron de forma precaria a la espera de realizar el interior de las nuevas dependencias en piedra cuando sus arcas se lo permitiesen.

Es probable que la ampliación del Hospital respondiese simétricamente a lo planteado en el proyecto de Egas (e incluso la podría haber trazado él mismo puesto que visitó la fábrica hasta 1517), disponiéndose planimétricamente una planta de cruz griega. Este argumento se basa en el análisis de sus elementos constructivos:

REMATE NOROESTE

Las fotos que se conservan de la rehabilitación acaecida a mediados del siglo XX muestran que el muro Este y su imponente cornisa (que circunda el edificio primigenio en sus muros Este, Sur y Oeste, y continúa a lo largo de la ampliación por el muro Este) no terminaban en la esquina actual NE sino que tendrían un mayor recorrido ya que en vez de estar bien trabados, los sillares se presentaban dentados, lo que indica que dicha ampliación del Hospital Real en el siglo XVI tendría mayores dimensiones que las actuales.

Probablemente el perímetro de la ampliación inicial se modificó en época Barroca, al substituir las dependencias de madera por los patios pétreos actuales, cuyo ajuste a las nuevas dimensiones interiores implicaría acotar la longitud perimetral del Hospital, momento en el cual se dejó la esquina NE sin trabar.

Será finalmente con el proyecto del Parador a mediados del siglo XX, cuando se uniformice la altura de la cornisa (que se encontraba bastante desvirtuada en las fachadas Oeste y Norte) y se rehaga el encuentro NE.

GÁRGOLAS

Las fachadas Sur y Este presentan gárgolas mal distribuidas, algo que responde a posteriores obras de saneamiento de los muros, en las cuales descuidaron estos elementos. Si equidistribuimos las gárgolas de la fachada Sur obtenemos una distancia razonable de 15 pies o 5 varas entre gárgolas. Siguiendo el mismo criterio, atribuimos esta distancia entre gárgolas a la fachada Este, obteniendo 


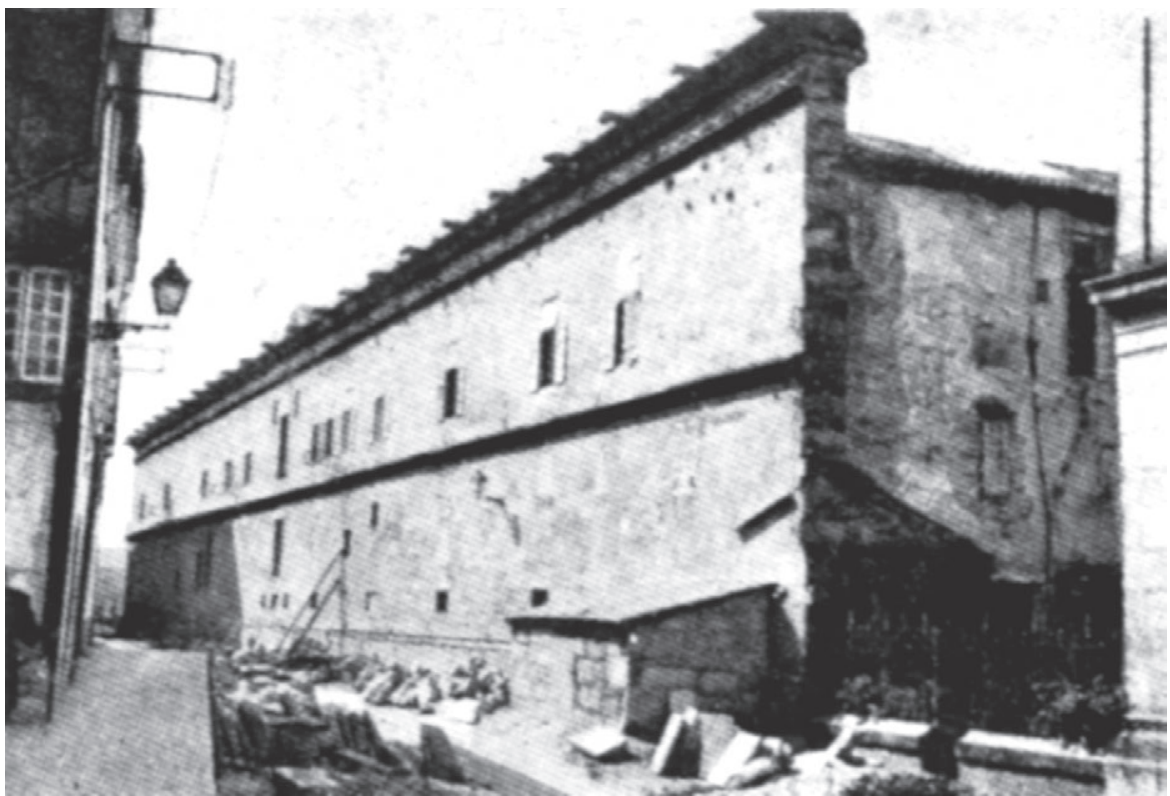

Fig. 10. Fotografía encuentro esquina Noreste (hacia 1950). Revista Nacional de Arquitectura, Madrid, año XIV, 156 (1954), pág. 8.

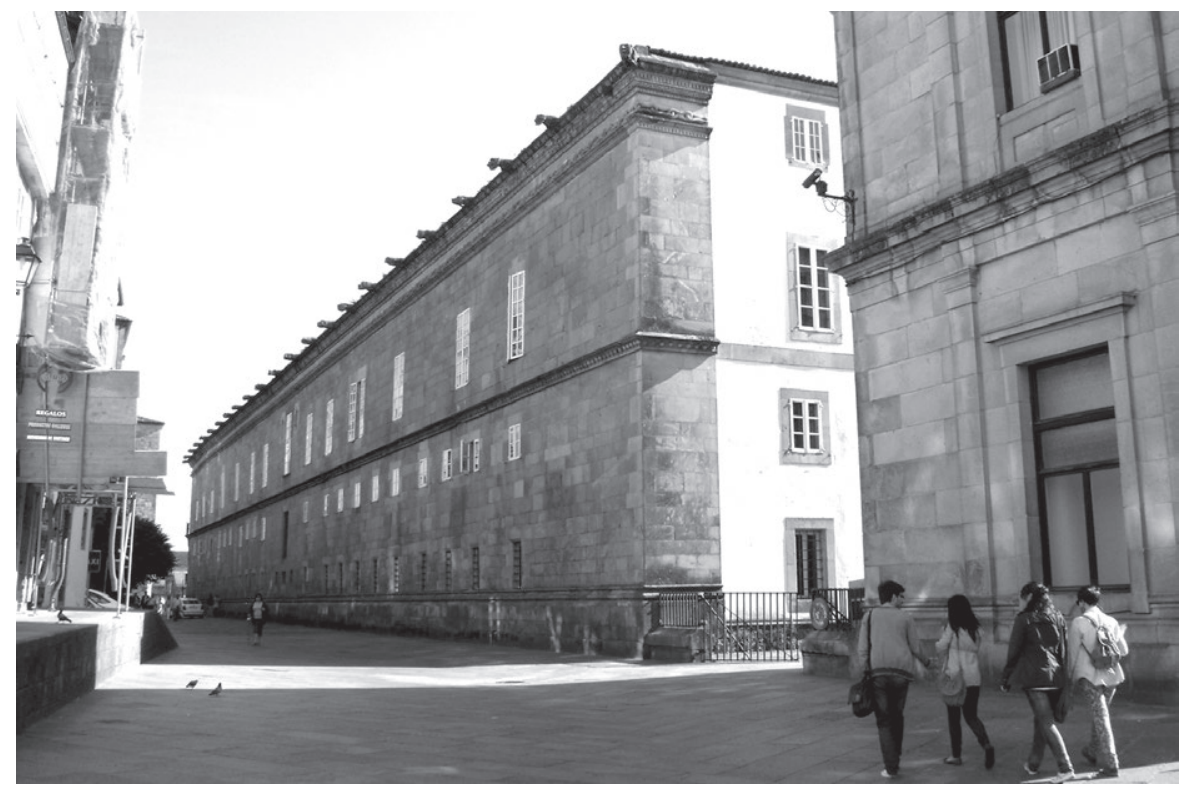

Fig. 11. Fotografía encuentro esquina Noreste (actual). Fotografía propia. 


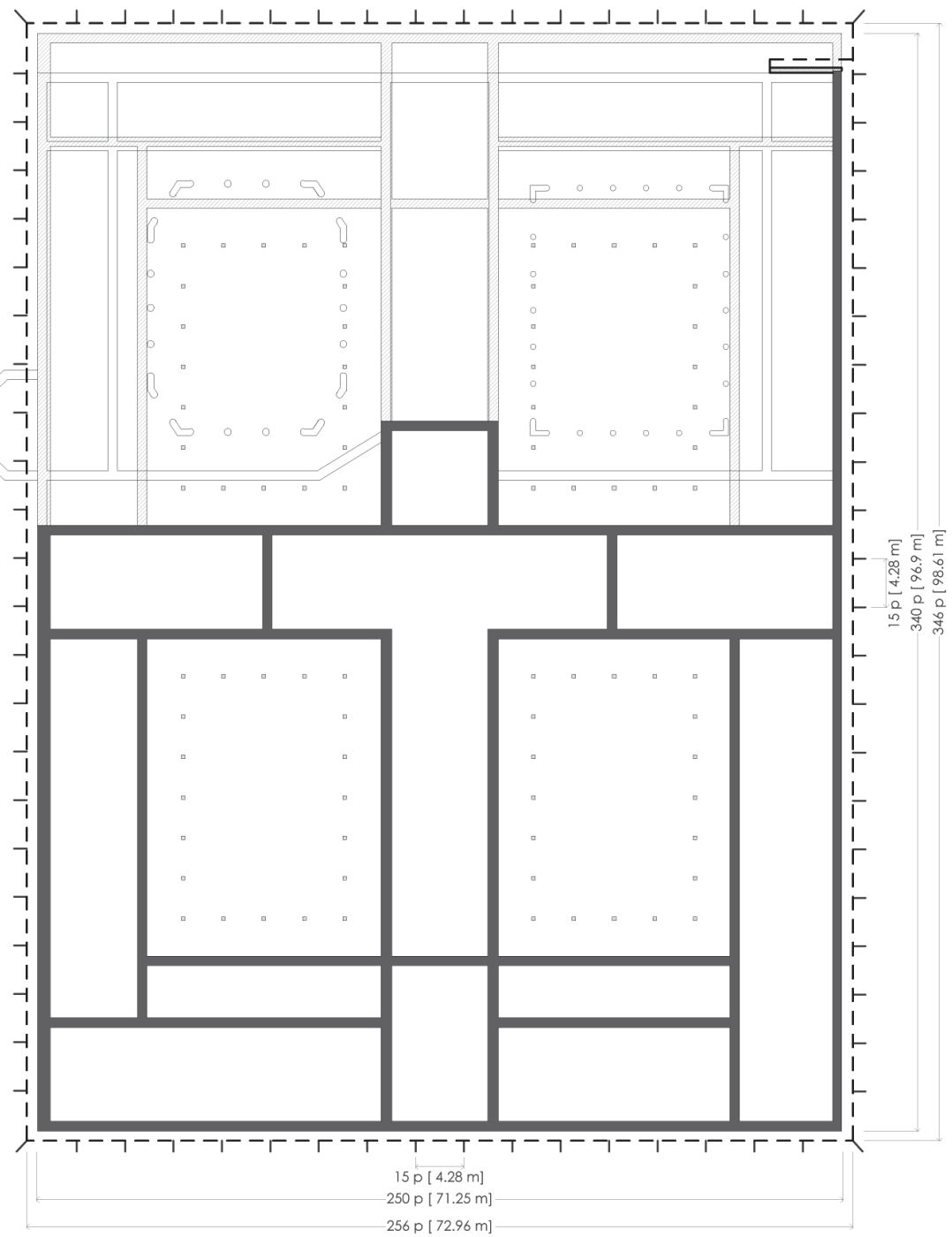

S.XVI $\square$ S.XVIII $\square$ s.XX - gárgolas - - cornisa $\square$ Hipótesis Ampliación S. XVI

\begin{tabular}{|c|c|c|c|c|}
\hline HOSPITAL REAL Santiago de Compostela & e: $1 / 750$ & 0 & $855 \mathrm{~m}$ & $21^{\prime} 375 \mathrm{~m}$ \\
\hline HIPÓTESIS AMPLIACIÓN & 1pie: 0’285m & 0 & $30 p$ & $75 p$ \\
\hline
\end{tabular}

Fig. 12. Hospital Real, Hipótesis Ampliación. Plano propio. 

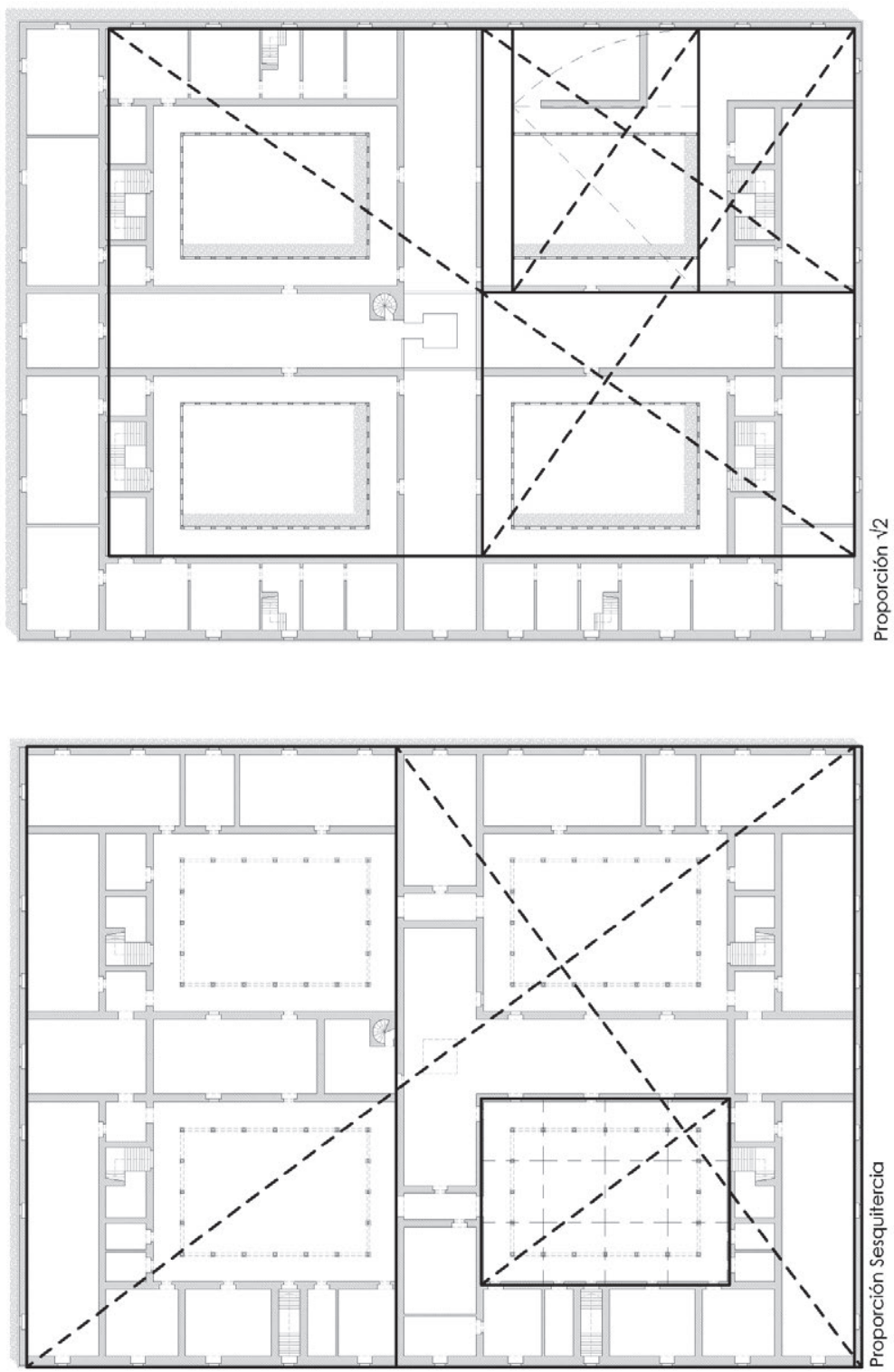

\begin{tabular}{l|l|llll} 
HOSPITAL REAL Santiago de Compostela & e: $1 / 750-$ & 0 & $8^{\prime} 55 \mathrm{~m}$ & $21^{\prime 375 m}$ \\
HIPÓTESIS AMPLIACIÓN Análisis Prop. & 1 pie: $0^{\prime} 285 \mathrm{~m}$ & 0 & $30 \mathrm{p}$ & $75 \mathrm{p}$
\end{tabular}

Fig. 13. Hospital Real, Hipótesis Ampliación. Análisis proporcional. Plano propio. 
justamente 24 gárgolas en el hipotético plano del Hospital Real diseñado con sus dos fases simétricas, por lo que no sorprende que hoy en día haya 23 gárgolas en esta fachada, que son las que llegaban hasta el muro Este cuando el Hospital Real se rehabilitó como Parador a mediados del siglo XX, época en la que le faltaba la esquina del ángulo NE, donde estaría ubicada la vigesimocuarta gárgola.

La planimetría de la hipotética ampliación del Hospital Real en planta de cruz griega también seguiría la secuencia de proporciones de la traza primigenia, así pues la totalidad de la planta de cruz griega se inscribe en un rectángulo de razón sesquitercia (3/4) (250 x 340 p.), y del mismo modo, la secuencia escalar $\sqrt{2}(7 / 5)$ prosigue y encaja en la distribución interior de este cuerpo simétrico $(75 \mathrm{x} 106 \mathrm{p}$. - 106 x 150 p. - 150 x 212 p. -212 x 300 p.).

PoRTADA DEL HOSPITAL

Aunque la portada del Hospital Real ya no fue obra proyectada por los maestros Egas; debido a su cercanía cronológica y su gran valía hacemos una pequeña reseña y análisis sobre dicha obra.

La portada en sí es el afuera-del-edificio, el cual no se debe entender como una simple consecuencia del interior, sino que tiene un peso importante al pertenecer al adentro-de-la-ciudad ${ }^{39}$ que es el ámbito público del edificio, por lo tanto una vez realizado el grueso del edificio vieron la necesidad de dignificar también su exterior para mostrar a la urbe el significado y finalidad de tan magna obra. El frons aedis o frente del edificio conviene realizarlo con gran esplendor para la honra de los Reyes Católicos.

El estilo ornamental denominado Plateresco se introdujo en Galicia con la portada del Hospital Real, contratada en 1518 a los maestros Guillén Colás y Martín de Blas y realizada entre 1519-1520, fechas muy posteriores al fallecimiento de los Reyes Católicos, y es que su promotor fue el humanista don Diego de Muros III, que era el administrador del Hospital Real.

Guillén Colás y Martín de Blas eran dos maestros franceses que estaban ligados a la figura de Juan del Castillo y Nicolás de Chanterenne, puesto que trabajaban a sus órdenes en el Monasterio de los Jerónimos de Belem. Martín y Guillén siempre trabajaron bajo las órdenes de otros maestros, no se les conoce otra obra propia, por lo tanto es lógico pensar que don Diego de Muros III no fiaría la parte visualmente más importante del edificio a dos maestros que no aportasen garantías. Además está por otro lado el hecho de que tanto Chanterenne como Castillo trabajaron en las obras del Hospital compostelano: el primero esculpió la mayoría de las esculturas de la capilla del Hospital en 1511, las cuales fueron

\footnotetext{
${ }_{39}$ J. Arnau Amo, La teoría de..., vol. II. , pág. 116.
} 
la primera muestra de escultura renacentista en Galicia, mientras que del segundo existe constancia documental de que, cuando menos, trabajó en las obras del Hospital en septiembre de $1513^{40}$.

Si bien adscribimos con meridiana claridad la autoría de la traza de la Portada del Hospital Real a Chanterenne o a Castillo, a falta de algún documento que lo esclarezca definitivamente, no nos podemos posicionar con uno u otro ya que por un lado Nicolás de Chanterenne tuvo gran notoriedad en el Hospital Real al haber realizado las esculturas de la capilla, siendo en torno al 1520 el escultor más importante del Renacimiento en Portugal ${ }^{41}$, pero por otro Juan del Castillo realiza en 1520 un pagamento a la mujer de Martín de Blas por ciertos trabajos realizados, cuando justamente en aquel momento Blas estaba a trabajar en la portada de Hospital Real ${ }^{42}$.

DESCRIPCIÓN: La portada del Hospital Real podría identificarse como una fachada de tradición gótica en cuanto a su adhesión al muro exterior del edificio como fachada-retablo, pero presenta una serie de principios reguladores que la proporcionan armónicamente, algo inherente al concepto renaciente del tipo que utiliza: un Arco del Triunfo Romano.

La portada presenta una riquísima decoración que la invade, mostrándonos un complejo programa iconográfico a relacionar con el sentido y finalidad del edificio hospitalario, destinado no sólo a la curación del cuerpo sino también a la regeneración del alma ${ }^{43}$.

Antonio Aguayo ${ }^{44}$ realiza una magnífica interpretación del programa iconográfico, el cual organiza su diseño mediante una arcada con múltiples arquivoltas cargadas de grutescos entre los que aparece la Casa Real: Felipe y Juana a los laterales y en la clave Carlos, pero ante ellos, presidiendo el conjunto, se

\footnotetext{
${ }^{40}$ Ricardo NunEs DA SiLVA, "Joao de Castilho. Entre Vila do Conde e Santiago de Compostela (1513): a transferência de conhecimentos e a mobilidade artística do mestre trasmiero", en Isabel Cruz Almeida y Maria Joao Neto (eds.), Sphera mundi. Arte e cultura no tempo dos descobrimentos, Lisboa, Centro Cultural de Belén, 2015, págs. 225-250.

${ }^{41}$ María Dolores Vila JATO, "El Hospital Real de Santiago y el arte portugués", en Diego Suárez Quevedo (dir.), Anales de la Historia del Arte, 4, Homenaje al Profesor Dr. D. José Ma de Azcárate y Ristori, Madrid, Facultad de Geografía e Historia, 1993-1994, pág. 304.

${ }^{42}$ Ricardo Nunes DA SILVA, "Entre los dos lados de la frontera: la presencia de Joao de Castilho en la obra del Hospital Real de Santiago de Compostela (1513)", en Begoña Alonso Ruiz y Juan Clemente Rodríguez Estevez (coords.), II Congreso Internacional de Arquitectos del Tardogótico. Sevilla, 12-15 noviembre 2014, [en prensa].

${ }^{43}$ María Dolores Vila Jato, O Renacemento, A Coruña, Sada, Edicios Do Castro, 1993, pág. 66.

María Dolores Vila Jato, "El primer Renacimiento Galaico-Portugués", en Xosé Carlos Valle Pérez (coord.), Do Tardogótico ó Manierismo. Galicia e Portugal, Fundación Pedro Barrié de la Maza / Fundaçao Calouste Gulbenlian, 1995, págs. 133-177.

${ }^{44}$ Antonio Aguayo, Simbolismo en las fachadas renacentistas compostelanas, A Coruña, Ediciós do Castro, 1983, págs. 19-63.
} 
encuentran en las enjutas los tondos de los Reyes Católicos, verdaderos valedores del Hospital Real. La arcada está flanqueada a cada lado por un triple sistema de pilastras y retropilastras que presentan un pronunciado basamento sobre el que arrancan fustes y entablamentos superpuestos. Los fustes de las pilastras están decorados con grutescos, por su parte los interpilastrados se configuran como calles en las que se asientan gran parte de la carga escultórica del conjunto. Encima de la arcada aparece una imposta que marca la división iconoclástica de la portada ya que hasta aquí se configuraba el espacio terrenal, así pues las esculturas del interpilastrado inferiores son Adán y Eva, representando al ser humano y al pecado, y en las pilastras más próximas al centro, entre los grutescos, aparecen cualidades que deberá atesorar el ser humano en vida, como son la templanza, la fortaleza, la justicia y la prudencia, para así poder ser digno de ascender al Reino de los Cielos, que se halla en el cuerpo superior. Entiéndase aquí que la Casa Real también se sitúa en el cuerpo bajo y por tanto son terrenales, pero se encuentra por encima de Adán y Eva y de las cualidades que el hombre ha de buscar en vida, lo que hace suponer que ellos ya las poseen y que están a medio camino entre Dios y los hombres.

El cuerpo superior lo podemos estructurar en tres fajas horizontales, en la inferior tenemos un gran friso central en el que se disponen los doce apóstoles, sobre ellos se encuentra una inscripción que consagra a Fernando e Isabel como peregrinos de Santiago y promotores del Hospital; la faja central llega hasta el remate superior de las pilastras, en ella se halla una ventana en el centro secundada por varios personajes, los más cercanos: Jesús a su derecha y María y el Niño a su izquierda; y en la faja superior se dispone una crestería con ángeles tocando instrumentos musicales.

Aquí entendemos que resulta acertado el comentario de Antonio Aguayo, que ve probable que en el lugar de la ventana se situara primigeniamente la imagen de Dios, ya que es el centro y cúspide de la composición de la portada, y su imagen no aparece en ninguna parte de la composición.

Interpretaciones recientes del conjunto escultórico marcan la posibilidad de que parte de la labor escultórica de la portada haya sido realizada con posterioridad a la muerte de los maestros Guillén Colás y Martín de Blas en 1522 por los talleres de Cornielles de Holanda y el maestro Arnao, puesto que mientras que buena parte de la imaginaría de la portada mantiene los trazos propios de la escultura hispano-flamenca, ciertas imágenes como las de Adán, Eva, San Pedro y San Juan Bautista, con su contrapposto, presentan un factura renacentista ${ }^{45}$.

\footnotetext{
45 Juan Monterroso Montero, "Escultura compostelana en pedra, s. XVI e XVII", en Antón Pulido Novoa (dir.), Artistas galegos. Escultores, Vol. 5. Séculos XVI e XVII, Vigo, Nova Galicia Edicións, 2004, págs. 368-413.
} 
MÉTRICA Y FORMA: Se utilizó el mismo pie $(28,50 \mathrm{~cm}$.) que rige el resto de la fábrica sanitaria.

La portada tiene tres grupos de pilastras pareadas que enmarcan la arcada de la entrada, y cuyas distancias a ejes son 18 p. las pilastras más céntricas, 26 p. las siguientes y 30 p. las de los extremos. En cuanto a su altura total es de 45 p., que viene a ser prácticamente la totalidad del lienzo en el que se inscribe. Como comentamos anteriormente, se divide iconográficamente en dos partes, la terrenal que tiene una altura de 25 p., y sobre ella la celestial con los 20 p. restantes, divididos en tres fajas de 8 p., 5 p. y 7 p.

Si bien estas medidas genéricas resultan claras, no ocurre lo mismo con las particulares de las pilastras, que se pierden y traban continuamente al intercalar molduras horizontales. Ello es debido, como ya se argumentó anteriormente, al hecho de que para la confección de la fachada no se han guiado por la modulación particular del orden de las pilastras, sino que lo que prevalece son unos principios reguladores que articulan y aportan unidad al conjunto y que son los que a fin de cuentas nos hablan de una nueva mentalidad a la hora de afrontar este proyecto.

La configuración compositiva de las dimensiones generales de la fachada se basa en la proporción sesquiáltera (3/2) que engloba las medidas globales del conjunto, además de aparecer en el segundo cuerpo y en la arcada con sus arquivoltas. Las grandes pilastras del conjunto también armonizan con el resto al encajar sus ejes en proporciones claras respecto a la altura total de la Portada: las pilastras más céntricas presentan una relación dupla sesquiáltera $(5 / 2)$ y las siguientes se basan en la medida cierta $\sqrt{3}$. Para finalizar hacemos también mención a la proporción áurea y la dupla, que aparecen componiendo relaciones más particulares.

Debemos por lo tanto entender que la decoración plateresca se utilizó tanto para obras con composiciones marcadamente góticas como para otras incipientemente renacentistas, por poner ejemplo de ello mencionamos las fachadas de la Universidad de Salamanca y del convento de San Esteban de Salamanca, que junto con la del Hospital Real compostelano son prueba evidente de la nueva mentalidad a la hora de conformar el espacio, mientras que otras como la Puerta de la Pellejería en la Catedral de Burgos o la portada del Hospital de Santa Cruz de Toledo se presentan con criterios proporcionales y compositivos propios del gótico.

\section{HiPÓTESIS SOBRE LA FIGURA DE DIEGO DE MUROS III}

Aunque no cabe duda de que los promotores principales de esta fábrica son los Reyes Católicos, hay que tener en cuenta la importancia que tuvo en la realización 


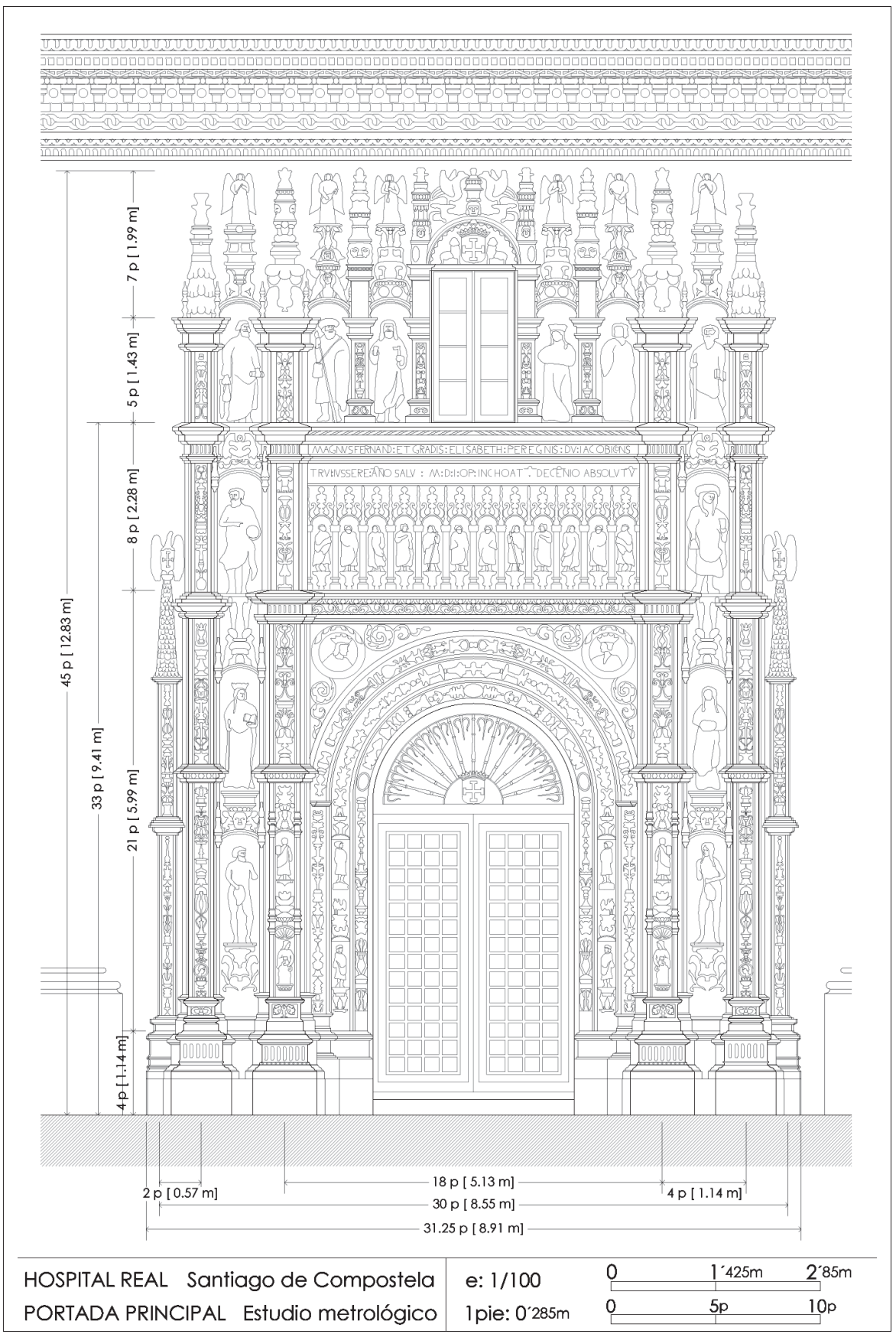

Fig. 14. Hospital Real, Portada principal. Estudio metrológico. Plano propio. 


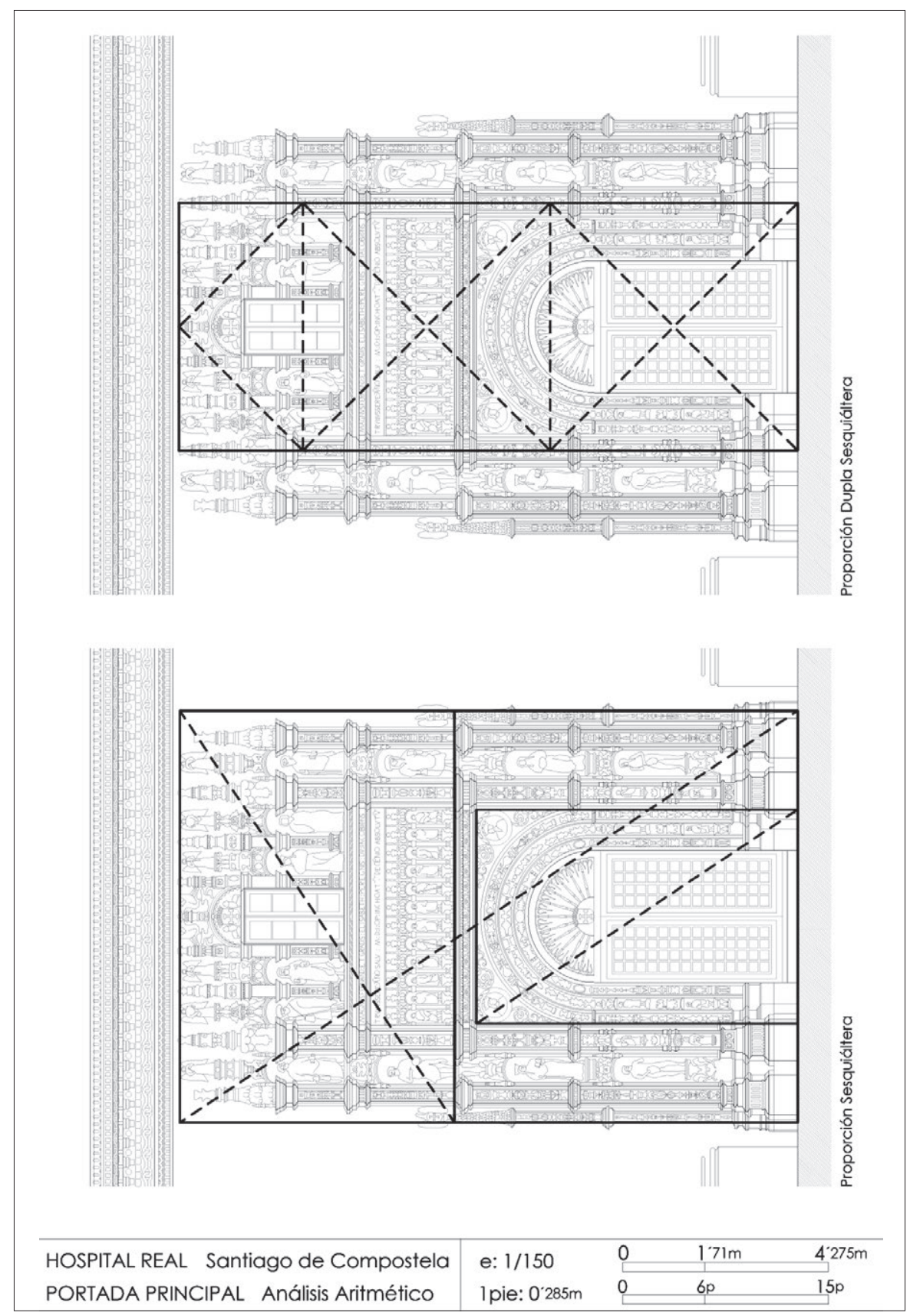

Fig. 15. Hospital Real, Portada principal. Análisis aritmético.

Proporción sesquiáltera - dupla sesquiáltera. Plano propio. 

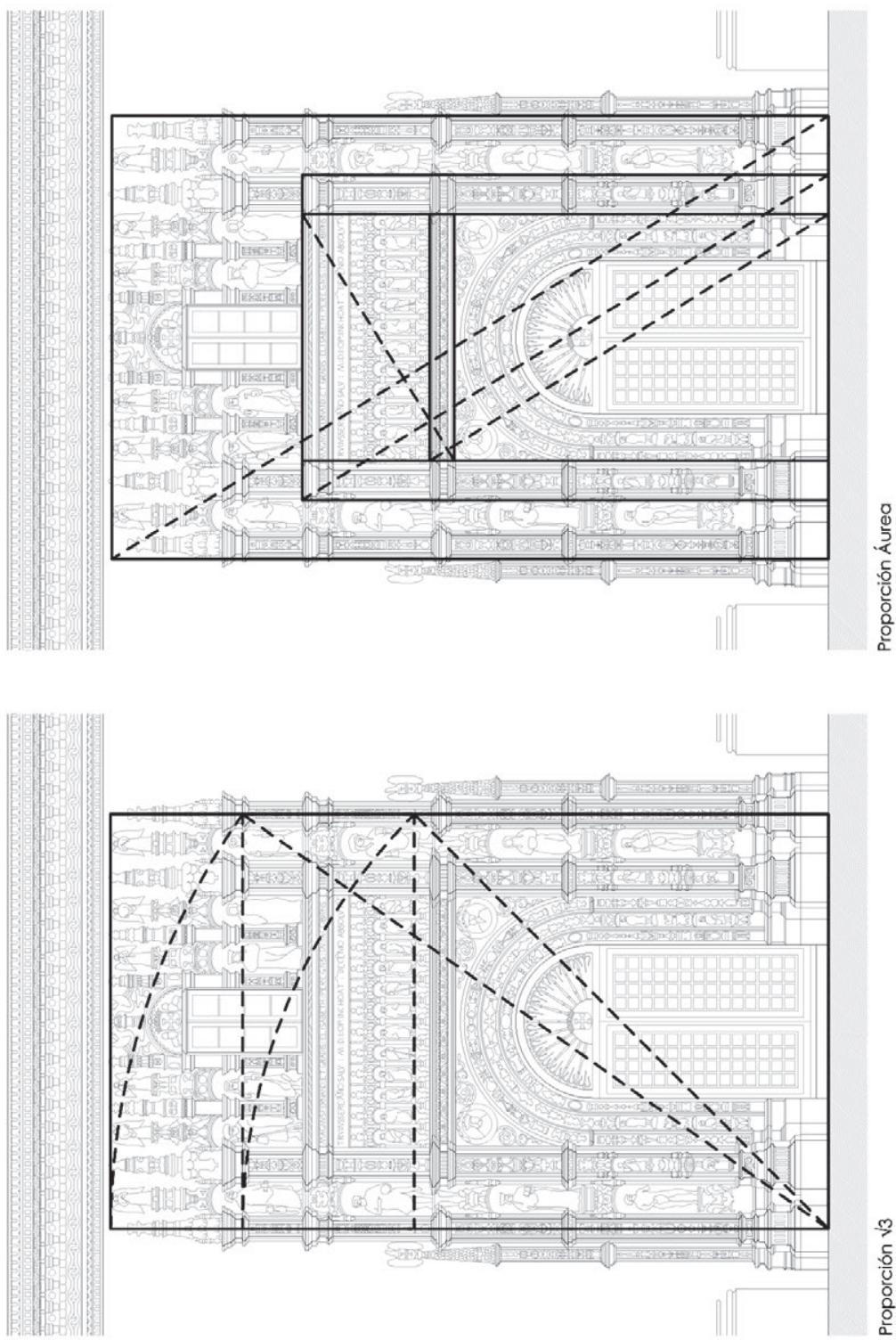

\begin{tabular}{l|llll} 
HOSPITAL REAL Santiago de Compostela & e: $1 / 150$ & 0 & $171 \mathrm{~m}$ & $4.275 \mathrm{~m}$ \\
PORTADA PRINCIPAL Análisis Geométrico & 1 pie: $0.285 \mathrm{~m}$ & 0 & $6 \mathrm{p}$ & $15 \mathrm{p}$
\end{tabular}

Fig. 16. Hospital Real, Portada principal. Análisis geométrico. Proporción $\sqrt{3}$ - áurea. Plano propio. 
del Hospital don Diego de Muros III, ilustre personaje que ocupó, entre otros, el cargo de secretario del cardenal don Pedro González de Mendoza (1484-1495), Deán en la mitra compostelana (1492-1505), Capellán Real (1502-1525), obispo de Mondoñedo (1505-1512) y obispo de Oviedo (1512-1525).

A don Diego de Muros III le tenía en gran estima el cardenal don Pedro González de Mendoza, bajo el que promocionó a tenor de la amistad que profesaban el Gran Cardenal y don Diego de Muros I, tío de su homónimo. En 1491, los Reyes le otorgaron la Chantrería de Santiago, pero la oposición de Alonso II de Fonseca le impidió disponer del cargo (debido a las disputas entre el arzobispo y Muros I). Al año siguiente quedó vacante el puesto de Deán, que sí ocupó Diego en 1492, aunque no presidió las reuniones capitulares hasta 1495, lo que hace suponer que siguió bajo el amparo del Cardenal Mendoza hasta su fallecimiento, en enero de $1495^{46}$.

Ya inmerso en la vida compostelana centra sus esfuerzos en impulsar el Estudio General recién fundado por Lope de Marzoa, hasta tal punto que cuando en 1771 se constituye el escudo de la Universidad Compostelana, además de las armas de Castilla, León y Galicia, en el escudo universitario también van a aparecen las armas de sus principales benefactores históricos: Lope de Marzoa, Diego de Muros III y Alonso de Fonseca III ${ }^{47}$.

En 1499 los Reyes Católicos delegaron en él la responsabilidad de convenir y concertar la obra del Hospital Real de Santiago de Compostela, siendo nombrado oficialmente su administrador perpetuo, de este modo derivaron sobre él toda la responsabilidad de llevar a buen puerto la obra. Además de la organización administrativa del Hospital, acometió la organización interna de la vida hospitalaria elaborando sus Ordenanzas entre 1509-1513, promovió la adquisición de solares y dotación de aguas durante 1501-1510, e incluso realizó la contratación de obras con los principales maestros ${ }^{48}$.

Hasta tal punto cumplió su cometido que siguió atendiendo la fábrica compostelana cuando ya estaba asentado como obispo en la sede ovetense, otorgando de sus propios fondos en 1518 (ya fallecidos los Reyes Católicos) dinero para la realización de la portada principal de acceso a la fábrica, realizada por Guillén Colás y Martín de Blas.

\footnotetext{
${ }^{46}$ Salustiano Portela Pazos, Don Diego de Muros, Dean de Santiago, Santiago, Seminario Conciliar, 1944, págs. 9-11. Jose García Oro, Diego de Muros III y la cultura gallega del siglo XV, Vigo, Editorial Galaxia, 1976, págs. 21-36.

47 Yolanda Barriocanal López, El grabado compostelano del siglo XVIII, A Coruña, Fundación Pedro Barrié de la Maza, 1996, pág. 292-293.

48 Jose García Oro, Diego de Muros..., 1976, pág. 36.
} 
Desde los primeros años de su vida profesional don Diego de Muros III incorpora como emblema propio la cruz de Jerusalén ${ }^{49}$ como referente por haber sido secretario del cardenal don Pedro González de Mendoza ${ }^{50}$, cargo con el que dirigió e intervino en las obras del Colegio Mayor de Santa Cruz en Valladolid, siendo su primer consiliario ${ }^{51}$.

Y es justamente esta cruz potenzada la que se emplea en el Hospital Real como símbolo heráldico para sus diversas manifestaciones, ya que aparece representada en múltiples piezas de vajillas, botamen de farmacia y elementos arquitectónicos ${ }^{52}$. En la cantería la encontramos en las enjutas de los arcos del primer piso de los patios delanteros del Hospital Real, cuyo referente directo es el Colegio Mayor de Santa Cruz en Valladolid, que dispuso idéntica seña en la misma ubicación. Del mismo modo, en la portada que en 1518 promovió y costeó Diego de Muros III, aparece la cruz de Jerusalén en los cuatro puntos extremos de su composición: en el centro superior en el dintel de la ventana, en el centro inferior en la rejería de la puerta de acceso y a mitad de altura en los laterales, en las águilas que se apoyan sobre las pilastras excéntricas.

Por lo tanto, una vez rastreada la figura de don Diego de Muros III, clave en la obra áulica compostelana, nos postulamos en la hipótesis de que Muros III plasmó en la fábrica hospitalaria su propia rúbrica.

Esta cruz potenzada, muy al contrario de causar conflicto alguno en la fábrica áulica, está en perfecta sintonía con la Corona puesto que los Reyes Católicos también la dejaron plasmada en fábricas como San Juan de los Reyes en Toledo

\footnotetext{
${ }^{49}$ Salvador Andrés Ordax, "Autoridad Plástica y eco fundacional del Colegio de Santa Cruz de Valladolid", en F. Llamazares y J. C. Vizuete (coord.), Arzobispos de Toledo, mecenas universitarios, Cuenca, Universidad de Castilla-La Mancha, 2004, págs. 213-239. Salvador AndrÉs OrdAX, El Cardenal y Santa Cruz: V Centenario del Cardenal Mendoza, Valladolid, Universidad de Valladolid, 1995, págs. 26, 55. María Jesus Bao Varela, "Retrato de D. Diego de Muros III", en José Manuel García Iglesias (com.), Gallaecia fulget (1495-1995), cinco siglos de historia universitaria, Santiago de Compostela, Universidade de Santiago de Compostela, 1995, pág. 204. Ángel SicART JiméNez, "La miniatura del pleito entre Alonso de Fonseca y Diego de Muros", Compostellanum, vol. 24 (1979), págs. 173-181.

${ }^{50}$ Don Pedro González de Mendoza, destacadísimo personaje de la segunda mitad del siglo XV que fue nombrado por Sixto IV Cardenal bajo la advocación de Santa María in Dominica, aunque luego él la cambio por la de Santa Cruz. Mendoza sufragó, entre muchas otras obras, todos o parte de los gastos del Colegio Mayor de Santa Cruz en Valladolid, del Hospital de la Santa Cruz en Toledo, obras en Sevilla en la iglesia de la Santa Cruz, en Roma la reedificación completa de la iglesia de la Santa Cruz y en Jerusalén la consolidación de la iglesia del Santo Sepulcro y la construcción de otro templo en honor a la Santa Cruz.

${ }^{51}$ Salustiano Portela Pazos, Decanologio de la SAM Iglesia Catedral de Santiago de Compostela, Santiago de Compostela, Seminario Conciliar, 1944, pág. 326.

${ }^{52}$ Carlos de Aracil, "Elementos heráldicos en el Hostal de los Reyes Católicos -Santiago de Compostela-", Anuario Brigantino, 36 (2013), pág. 374.
} 
o el monasterio de las clarisas en Segovia, ya que ostentaban el título de Reyes de Jerusalén. Pero entendemos que la iniciativa de dicha rúbrica como símbolo para el Hospital Real se debió en mayor medida a la intervención de Muros III, debido a que los Reyes Católicos consiguieron el título de Reyes de Jerusalén en 1504 al adherir el Reino de Nápoles a la Corona de Aragón, pero la cruz potenzada como símbolo del hospital ya se fraguaría con anterioridad a la conquista de Nápoles, puesto que no ha de ser casualidad que el mismo día en que los Reyes Católicos le otorgaron Poder y Memoria a Muros III para la construcción sanitaria (el 3 de mayo de 1499) fuese justamente el día en que se festejaba la Intervención de la Santa Cruz.

\section{Conclusiones}

Sobre el genuino tejido cultural peninsular de pasado musulmán, el panorama general de la cultura renacentista española se desarrolla, en torno al 1500, hacia dos direcciones: Flandes e Italia ${ }^{53}$, y en este contexto, la arquitectura civil de los hermanos Egas se alza como síntesis y confluencia de todas ellas, siendo una opción perfectamente válida y plenamente contemporánea.

$\mathrm{Su}$ vertiente Centroeuropea proviene de su ascendencia genealógica, con Egas Cueman y Hanequin de Bruselas a la cabeza, llegados a España a mediados del siglo XV. Dicha aportación se deja notar, aparte de por sus interesantísimas decoraciones, por las reglas estructurales que emplean, particularmente en la capilla o patios, donde obtiene sus dimensiones generales mediante relaciones aritméticas simples.

Su acercamiento al Quattrocento italiano, se realiza desde la perspectiva que tiene Filarete de la arquitectura y que se desprende de su tratado: figuras simples como contenedores de la totalidad de la obra, proceso de división modulada para el establecimiento derivado de las partes, de lo general a lo particular; basándose en la idea clásica y renaciente del corpus arquitectónico y por lo tanto oponiéndose frontalmente a los métodos aditivos de la construcción medieval, de lo particular a lo general. El acuerdo dimensional correspondiente a la plena noción clásica de la symmetria es la preocupación constante y obsesiva del Tratado filaretiano ${ }^{54}$, y como hemos comprobado, también del Hospital Real.

En cuanto al tejido propiamente peninsular, los hermanos Egas fijaron su taller y desarrollaron su principal labor profesional en Toledo. De su Catedral aprehendieron su distribución interior y la organización del repartimiento de naves y tramos,

\footnotetext{
53 Juan Manuel Martín García, "El arte en la época de los Reyes Católicos: Estado Moderno y Renacimiento", en Juan Manuel Martín García (ed.), Modernidad y cultura artística en tiempos de los Reyes Católicos, Granada, EUG, 2014, pág. 23.

54 J. Arnau Amo, La teoría de..., vol. III, págs. 7-15.
} 
que se disponen en relación áurea ${ }^{55}$, proporción que proviene de su conocimiento en Al-Ándalus, por lo que apareció en la España cristiana antes que la introdujesen como novedad gótica los franceses o que Luca Pacioli la desarrollase a finales del siglo XV en los círculos italianos de teorización arquitectónica. En Toledo estaba muy presente la arquitectura islámica, con la que el Hospital Real muestra ciertas concomitancias en varios aspectos: como en su concepción espacial, en esa forma de recorrer los espacios que se realiza por saltos o conexiones ortogonales en donde cada espacio conjuga sabiamente los efectos de contraste entre ambientes diferentes con los de ritmo, proporción y armonía dentro de cada volumen (véase en el Hospital Real el recorrido Zaguán-Distribuidor-Patio donde sus proporciones son Áurea-Cuadrado-Sesquitercia respectivamente). Ambas mantienen un gusto por la subordinación de la decoración a la arquitectura, localizada en los elementos de mayor dignidad, e incluso en el Hospital Real su composición de ritmos también prolifera en hábiles agregados combinatorios, aunque cambie el concepto islámico de plantas asimétricas distribuidas orgánicamente por otro simétrico y compacto.

Con todo ello comprendemos que la idea de superación de lo antiguo no se produjo en España desde una búsqueda ortodoxa de lo clásico exclusivamente, y es que cuando el nuevo lenguaje arquitectónico italiano hace su aparición en España, ya se había producido una modernización del lenguaje preexistente: el llamado tardogótico, con unas características específicas propias del panorama peninsular, de ahí que en la arquitectura española de este período la idea de modernidad se formulase a través de la dualidad formal ${ }^{56}$, que resulta evidente al leer la obra de Ingeniosa comparación entre lo antiguo y lo presente de Cristóbal de Villalón, publicada en 1539. Y es que por arquitectura Humanista no debemos clasificar tan sólo a aquella que parte del correcto empleo de los órdenes clásicos, puesto que dicha arquitectura se basa en su correspondencia con la naturaleza, y ello también puede derivar de las relaciones proporcionales de sus superficies y cuerpos $^{57}$, como así formula Egas en el Hospital Real.

Si bien la historiografía actualmente clasifica con cierta nitidez que el Hospital Real se realizó bajo la semántica del tardogótico, puesto que todos los maestros que intervinieron en ella estaban versados en el arte de cantería de tradición gótica, debemos argumentar qué es lo que nos aporta esta fábrica, independientemente de su etiqueta, ya que ciertamente torna parco el describir al Hospital Real como un

\footnotetext{
55 J. M. Merino de CÁceres, Metrología y composición..., pág. 398.

${ }^{56}$ Víctor NiETo, "Renovación e indefinición estilística, 1488-1526", en Víctor Nieto, Alfredo José Morales, Fernando Checa, Arquitectura del renacimiento en España, 1488-1599, Madrid, Ediciones Cátedra, S.A., 1989, pág. 16.

${ }^{57}$ Fernando MARÍAs, El largo siglo XVI, los usos artísticos del Renacimiento español, Madrid, Taurus, 1989, pág. 526.
} 
edificio tardogótico que simplemente aplicó una tipología planimétrica italiana; y es que tras el presente estudio, una vez diseccionada su metrología y composición, podemos afirmar que esta fábrica representa como pocas la perfecta conjunción de los dos sistemas arquitectónicos preponderantes en la época.

Al ser el Hospital Real un edificio civil que no estaba atado a los simbolismos y connotaciones eclesiásticas, Egas pudo introducir parámetros compositivos propios del Quattrocento italiano: la symmetría y el corpus arquitectónico. Los análisis planimétricos correspondientes nos muestran un edificio bien trabado, donde aparecen las proporciones aritméticas, que modulan todo el edificio y que son la translación numérica de acordes musicales armónicos (la quinta o proporción sesquiáltera y la quarta o porporción sesquitercia). La aritmética y la música en este edificio van entrelazadas con la geometría: la medida cierta $\sqrt{2}$ fue básica en el románico, y el número de oro Ø se introdujo en la península Ibérica con el Islam (del cual se apropiaron los cristianos) ${ }^{58}$. Por su parte la relación cosmológica queda patente en los puntos anteriores, ya que éstos nos aportan un esquema de relaciones que ordenan la arquitectura, un sistema proporcional, una búsqueda del edificio-ciudad, del microcosmos-macrocosmos, que relaciona cada parte con su todo, plasmando de este modo el orden cósmico en la arquitectura.

Por lo tanto, para el desarrollo proyectual de esta fábrica Egas se basó en las medidas ciertas, el principio de los números enteros pequeños y el sistema escalar, para aplicar las Artes Quadrivium (Artes que agrupan las disciplinas científicas relacionadas con las matemáticas: Aritmética, Geometría, Música y Cosmología) en el Hospital Real y con ello dignificar dicha fábrica, alcanzando como destreza espiritual o intelectual el status de Arte Mayor, resultando con ello una obra completamente imbuida en el espíritu Humanístico.

El mismo argumento ha de ser aplicado a la posterior realización de la portada principal de la fachada meridional, trazada probablemente por Juan del Castillo o Nicolás de Chanterenne, en la que el empleo de principios reguladores armonizan todo el conjunto. La única divergencia notable de esta arquitectura respecto a la primigenia de Egas reside en el hecho de que la portada introdujo en el panorama gallego la profusa decoración Plateresca, dejando atrás aquella gótica que aún atesoraba Egas.

Dicha portada fue costeada por don Diego de Muros III, ilustre humanista que entre obras promociona en 1517 del Colegio de San Salvador de Oviedo realizado en Salamanca para colegiales gallegos y asturianos, y cuyo emblema heráldico colegial es la cruz potenzada, como seña de su pasado mendociano, a la que acompañada en sus márgenes la leyenda: crucem sectemvr coetera avtem

58 J. M. MERINo de CÁceres, Metrología y composición..., pág. 398. 
luctvm pvtemvs. En esta primera aproximación a la figura de Don Diego respecto a su intervención en el Hospital Real, nos postulamos sobre la hipótesis de que este personaje ha sido determinante en todo el proceso de la obra hasta tal punto de plasmar su rúbrica en la fábrica, encubierta en parte por su sincronía con la heráldica áulica.

Por último queremos terminar reflexionando sobre la intervención en el Hospital Real de Rodrigo Gil de Hontañón. Este maestro a mediados del siglo XVI copaba el mayor prestigio y las mejores fábricas del panorama castellano y gallego. Su forma de entender la arquitectura se sistematiza en tres partes bien diferenciadas: Ordenación, Disposición y Hermosura. La Ordenación de la obra se hacía en base a sus trazas generales y sus proporciones. La Disposición englobaba la realización de las plantas, monteas y perspectiva. Y la Hermosura atendía a la limpieza, curiosidad y ornato, ocupando una posición subsidiaria frente a las anteriores ${ }^{59}$. Esto lo ratifican sus contratos de obra, donde determina detalles arquitectónicos, estructurales y planimétricos, pero rara vez concreta sus elementos ornamentales, a los que alude con términos genéricos como molduras a lo romano o muy bien fechos ${ }^{60}$.

El hecho de considerar la Hermosura complementaria a la Ordenación y Disposición, derivo probablemente a que en ocasiones dejase la decoración en manos del equipo de tallistas, con lo que en sus obras siempre existió un cierto eclecticismo decorativo, aunque tampoco es menos cierto que nunca empleó una decoración anacrónica, y menos en la época en la que intervino en la fábrica compostelana, puesto que pasada la mitad de la centuria sus realizaciones se presentaban libres de cualquier carga decorativa flamígera y plateresca. Si tenemos en cuenta intervenciones suyas en fábricas ya comenzadas por otros maestros, coetáneas a su peritaje de la fábrica compostelana, veremos que no realiza una repetición o mímesis formal del repertorio existente sino que sus intervenciones se distinguen claramente del maestro que lo precedió, como sucede en el transepto y presbiterio que realiza en la capilla del Colegio de Santiago Zebedeo en Salamanca (1548-1550) o en el cuerpo superior que inserta en la fachada Norte de la Catedral de Plasencia (1554-1558), en las que se aproxima a una correcta formulación de los órdenes clásicos, aunque como ya hemos comentado, ocupando un lugar secundario en su idea de intervención en dichas fábricas; por lo tanto resulta difícil argumentar a favor de adscribir la autoría de los claustros del Hospital Real a Rodrigo Gil de Hontañón más allá de la intervención que desglosamos con anterioridad.

\footnotetext{
${ }^{59}$ Simón GarCia, Compendio de architectura..., fol. 27-30.

${ }^{60}$ Antonio Casaseca Casaseca, Rodrigo Gil de Hontañón (Rascafría 1500-Segovia 1577), [Valladolid], Junta de Castilla y León, 1988, págs. 200 y ss.
} 


\section{BIBLIOGRAFÍA}

Aguayo, Antonio, Simbolismo en las fachadas renacentistas compostelanas, A Coruña, Ediciós do Castro, 1983.

Andrés Ordax, Salvador, “Autoridad Plástica y eco fundacional del Colegio de Santa Cruz de Valladolid”, en F. Llamazares y J. C. Vizuete (coord.), Arzobispos de Toledo, mecenas universitarios, Cuenca, Universidad de Castilla-La Mancha, 2004.

Andrés Ordax, Salvador, El Cardenal y Santa Cruz: V Centenario del Cardenal Mendoza, Valladolid, Universidad de Valladolid, 1995.

Aracil, Carlos de, "Elementos heráldicos en el Hostal de los Reyes Católicos -Santiago de Compostela-", Anuario Brigantino, 36 (2013), págs. 369-380.

Arnau Amo, Joaquín, La teoría de la arquitectura en los tratados, Albacete, Artes gráficas Flores, 1988.

Averlino "Filarete", Antonio, Tratado de arquitectura, edición de Pilar Pedraza, Vitoria-Gasteiz, Ephialte, Instituto de Estudios Iconográficos, 1990.

Arnau Amo, Joaquín, La teoría de la arquitectura en los tratados, Albacete, Artes gráficas Flores, 1988.

Bao Varela, María Jesus, "Retrato de D. Diego de Muros III”, en J. M. García Iglesias (com.), Gallaecia fulget (1495-1995), cinco siglos de historia universitaria, Santiago de Compostela, Universidade de Santiago de Compostela, 1995

Barriocanal López, Yolanda. El grabado compostelano del siglo XVIII, A Coruña, Fundación Pedro Barrié de la Maza, 1996.

Baquero, Aurelio, Bosquejo histórico del Hospital Real y General de Nuestra Señora de Gracia de Zaragoza, Zaragoza, Institución Fernando el Católico, 1952.

Bergier, Abate, Diccionario enciclopédico de teología, Tomo IV, trad. Ramón García Consul, Madrid, 1832.

Cambil Hernández, María de la Encarnación, Los hospitales de Granada: (siglo XVI-XXI) Tipología, Catálogo e historia, Granada, Universidad de Granada, 2010

Carmona, Mário, O Hospital Real de Todos os Santos da Cidade de Lisboa, Lisboa, 1954.

Casaseca Casaseca, Antonio, Rodrigo Gil de Hontañón (Rascafría 1500-Segovia1577), [Valladolid], Junta de Castilla y León, 1988.

Chueca Goitia, Fernando, Invariantes castizos de la Arquitectura Española, Madrid, Seminarios y Ediciones, 1971.

Cruz Cabrera, José Policarpo, "La escultura castellana en tiempos de Doña Isabel la Católica: de la tradición medieval a la modernidad humanista" en Juan Manuel Martín García (ed.), Modernidad y cultura artística en tiempos de los Reyes Católicos, Granada, EUG, 2014.

Durero, Alberto, De la medida, Jeanne Peiffer (ed.), Madrid, Akal, 2000.

Fernández Doctor, Asunción, El Hospital Real y General de Ntra. Sra. De Gracia de Zaragoza en el siglo XVIII, Zaragoza, Institución Fernando el Católico, 2000.

Fernández Rodríguez, Begoña, "La hospitalidad medieval, El hospital viejo de Santiago de Compostela”, en Memoria Artis, A Coruña, Xunta de Galicia, 2003. 
Fernández Gómez, Margarita, Codex Escurialensis 28-II-12, Libro de dibujos o antigüedades, Murcia, Patrimonio Nacional, 2000.

García, Simón, Compendio de architectura y simetría de los templos: conforme a la medida del cuerpo humano con algunas demostraciones de geometría, año de 1681, Valladolid, Colegio de Arquitectos de Valladolid, 1991.

García Guerra, Delfín, El Hospital Real de Santiago (1499-1804), A Coruña, Fundación Pedro Barrié de la Maza, 1983.

García Oro, José, Diego de Muros III y la cultura gallega del siglo XV, Vigo, Editorial Galaxia, 1976.

García Oro, José, Galicia en los siglos XIV y XV (Colección Galicia Histórica), A Coruña, Fundación Pedro Barrié de la Maza, 1987.

Gómez-Ferrer Lozano, Mercedes, Arquitectura en la Valencia del Siglo XVI, El Hospital General y sus artifices, Valencia, Albatros, 1998.

Goy Diz, Ana; Vila Jato, María Dolores, "Textos generales” en M. D. Vila Jato (coord.), Parador "dos Reis Católicos", Santiago de Compostela, un hotel con quinientos años, el más antiguo de Europa, Madrid, Paradores de Turismo de España, 1999.

Grande Nieto, Víctor, Proceso Metodológico y Compositivo del Renacimiento en Galicia, 1499-1657, tesis doctoral inédita, A Coruña, UDC, 2014.

Huerta Fernández, Santiago, "Las reglas estructurales del gótico tardío alemán" en M. Arenillas; C. Segura; F. Bueno; S. Huerta (eds.), Actas del Quinto Congreso Nacional de Historia de la Construcción, Burgos, 7-9 junio 2007, Madrid, Juan de Herrera, SedHC; CICCP; CEHOPU, 2007.

Iborra Bernard, Federico, "El problema de las fachadas asimétricas en la arquitectura residencial del tardogótico castellano", en Begoña Alonso Ruiz (ed.), La arquitectura tardogótica castellana, Entre Europa y América, Madrid, Silex, 2011.

Insua Cabanas, Mercedes, “Arquitectura Hospitalaria en Galicia”, en Xosé María García Iglesias (coord.), O Hospital Real de Santiago de Compostela e a hospitalidade no camiño de peregrinación, Santiago de Compostela, Xunta de Galicia, 2004.

Leistikow, Dankwart, Edificios hospitalarios en Europa durante diez siglos. Historia de la arquitectura hospitalaria, C. H. Boehringer Sohn, Ingelheim am Rhein, 1967.

Marías, Fernando, El largo siglo XVI: los usos artísticos del renacimiento español, Madrid, Taurus, 1989.

Marías, Fernando, "A arquitectura do clasicismo en Galicia” en J. M. García Iglesias (Com.), Galicia no Tempo, Santiago de Compostela, Xunta de Galicia, vol. I, 1991.

Martín García, Juan Manuel, "El arte en la época de los Reyes Católicos: Estado Moderno y Renacimiento", en Juan Manuel Martín García (ed.), Modernidad y cultura artística en tiempos de los Reyes Católicos, Granada, EUG, 2014.

Merino de Cáceres, José Miguel, Metrología y composición en la arquitectura medieval española, Madrid, ETSAM, Departamento de Composición arquitectónica, 2002.

Monterroso Montero, Juan, "Escultura compostelana en pedra, s. XVI e XVII", en A. Pulido Novoa (dir.), Artistas galegos. Escultores, Vol. 5. Séculos XVI e XVII, Vigo, Nova Galicia Edicións, 2004. 
Nieto, Víctor, "Renovación e indefinición estilística, 1488-1526", en V. Nieto, A. J. Morales, F. Checa. Arquitectura del renacimiento en España, 1488-1599, Madrid, Cátedra, S.A., 1989.

Nunes da Silva, Ricardo, "Entre los dos lados de la frontera: la presencia de Joao de Castilho en la obra del Hospital Real de Santiago de Compostela (1513)", en B. Alonso Ruiz; J. C. Rodríguez Estevez (coords.), II Congreso Internacional de Arquitectos del Tardogótico. Sevilla, 12-15 noviembre 2014, [en prensa].

Nunes da Silva, Ricardo, "Joao de Castilho. Entre Vila do Conde e Santiago de Compostela (1513): a transferência de conhecimentos e a mobilidade artística do mestre trasmiero", en I. Cruz Almeida; M. J. Neto (eds.), Sphera mundi. Arte e cultura no tempo dos descobrimentos, Lisboa, Centro Cultural de Belén, 2015.

Pereira, Paulo, "Construçoes na "Gran Estrada": O Caminho de Santiago e a Arquitectura Portuguesa (1400-1521)”, en X. C. Valle Pérez (coord.), Do Tardogótico ó Manierismo. Galicia e Portugal, Fundación Pedro Barrié de la Maza / Fundaçao Calouste Gulbenlian, 1995.

Pevsner, Nikolaus, Historia de la tipología de las arquitecturas, Barcelona, Gustavo Gili, 1979.

Portela Pazos, Salustiano, Decanologio de la SAM Iglesia Catedral de Santiago de Compostela, Santiago de Compostela, Seminario Conciliar, 1944.

Portela Pazos, Salustiano, Don Diego de Muros, Deán de Santiago, Santiago, Seminario Conciliar, 1944.

Rey Castelao, Ofelia, “A Historia do Real Hospital de Santiago”, en X. M. García Iglesias (coord.), O Hospital Real de Santiago de Compostela e a Hospitalidade no Camiño de Peregrinación, A Coruña, Xunta de Galicia, 2004.

Rosende Valdés, Andrés, “Los Reyes Católicos y Compostela: política y devoción”, Semata, 10 (1998), págs. 149-169.

Rosende Valdés, Andrés, El Grande y Real Hospital de Santiago de Compostela, Santiago de Compostela, Electa, 1999.

Sagredo, Diego, Medidas del romano, Toledo, Remón de Petras, 1526.

Sicart Jiménez, Ángel, "La miniatura del pleito entre Alonso de Fonseca y Diego de Muros", Compostellanum, vol. 24 (1979), págs. 173-181.

Valle Pérez, Xosé Carlos. Do tardogótico ó manierismo, Galicia e Portugal, Fundación Pedro Barrié de la Maza, Fundación Calouste Gulbenkian, Alva, 1995.

Vila Jato, María Dolores, O Renacemento, A Coruña, Sada, Edicios Do Castro, 1993.

Vila Jato, María Dolores, "El Hospital Real de Santiago y el arte portugués", en D. Suárez Quevedo (dir.), Anales de la Historia del Arte, 4, Homenaje al Profesor Dr. D. José Ma de Azcárate y Ristori, Madrid, Facultad de Geografía e Historia, 1993-1994.

Vila Jato, María Dolores, "El primer Renacimiento Galaico-Portugués”, en X. C. Valle Pérez (coord.), Do Tardogótico ó Manierismo. Galicia e Portugal, Fundación Pedro Barrié de la Maza / Fundaçao Calouste Gulbenlian, 1995.

Vila Jato, María Dolores; Goy Diz, Ana, "Textos generales” en M. D. Vila Jato (coord.), Parador "dos Reis Católicos", Santiago de Compostela, un hotel con quinientos años, el más antiguo de Europa, Madrid, Paradores de Turismo de España, 1999.

Villaamil y Castro, José, "Documentos copiados en el archivo del Gran Hospital Real de Santiago”, Galicia Histórica. Colección Diplomática, 1 (1901), págs. 586-587. 
Wilkinson, Catherine, The Hospital of Cardinal Tavera in Toledo, Nueva York, Garland Publishind, 1977.

Yarza Luaces, Joaquín, Los Reyes Católicos: paisaje artístico de una monarquía, Madrid, Ediciones Nerea S.A., 1993. 